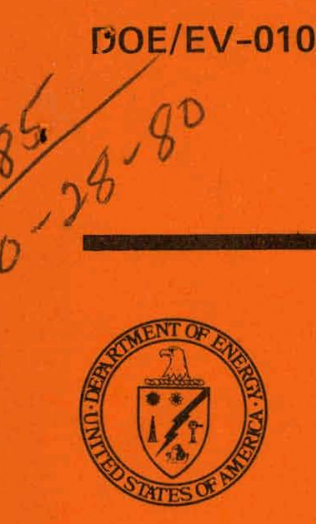

U.S. Department of Energy

Assistant Secretary for Environment

Office of Environmental Assessments

Ha.

1881

September 1980

Technology Assessments Division

A Technology

Assessment of

Solar Energy Systems

\title{
Alcohol Production from Agricultural and Forestry Residues
}

MASTER

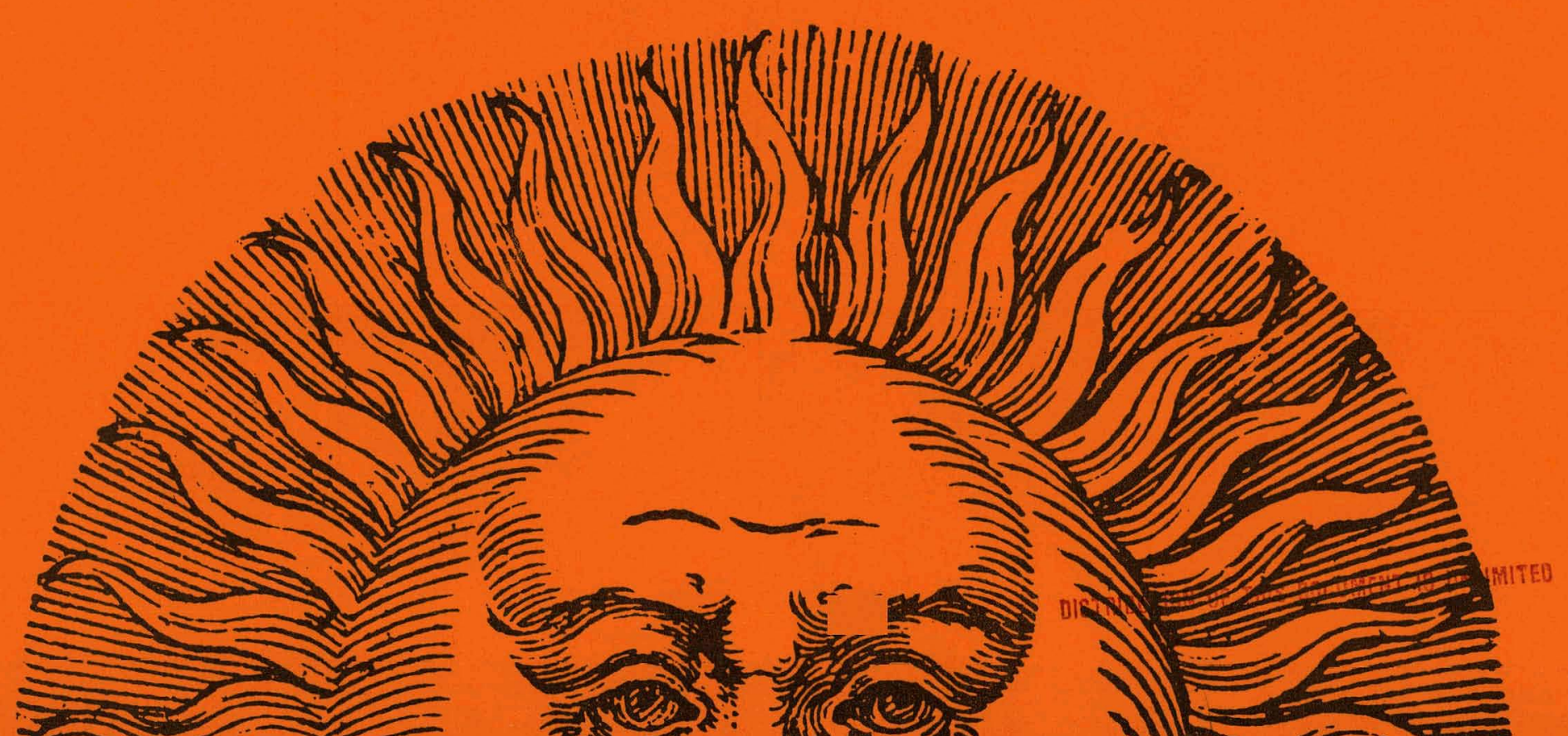




\section{DISCLAIMER}

This report was prepared as an account of work sponsored by an agency of the United States Government. Neither the United States Government nor any agency Thereof, nor any of their employees, makes any warranty, express or implied, or assumes any legal liability or responsibility for the accuracy, completeness, or usefulness of any information, apparatus, product, or process disclosed, or represents that its use would not infringe privately owned rights. Reference herein to any specific commercial product, process, or service by trade name, trademark, manufacturer, or otherwise does not necessarily constitute or imply its endorsement, recommendation, or favoring by the United States Government or any agency thereof. The views and opinions of authors expressed herein do not necessarily state or reflect those of the United States Government or any agency thereof. 


\section{DISCLAIMER}

Portions of this document may be illegible in electronic image products. Images are produced from the best available original document. 
Printed in the United States of America

Available from

National Technical Information Service

U.S. Department of Commerce

5285 Port Royal Road

Springfield, VA 22161

NTIS price codes

Printed Copy: $\quad \$ 7.00$

Microfiche Copy: $\$ 3.50$ 


\section{A Technology Assessment of Solar Energy Systems}

\section{Alcohol Production from Agricultural and Forestry Residues}

Prepared by:

Argonne National Laboratory

\section{U.S. Department of Energy \\ Assistant Secretary for Environment Office of Environmental Assessments Washington, D.C. 20545}

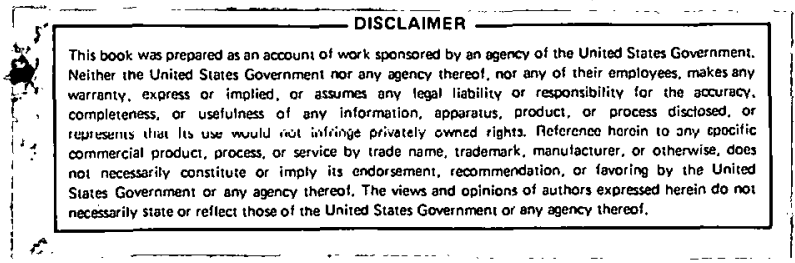




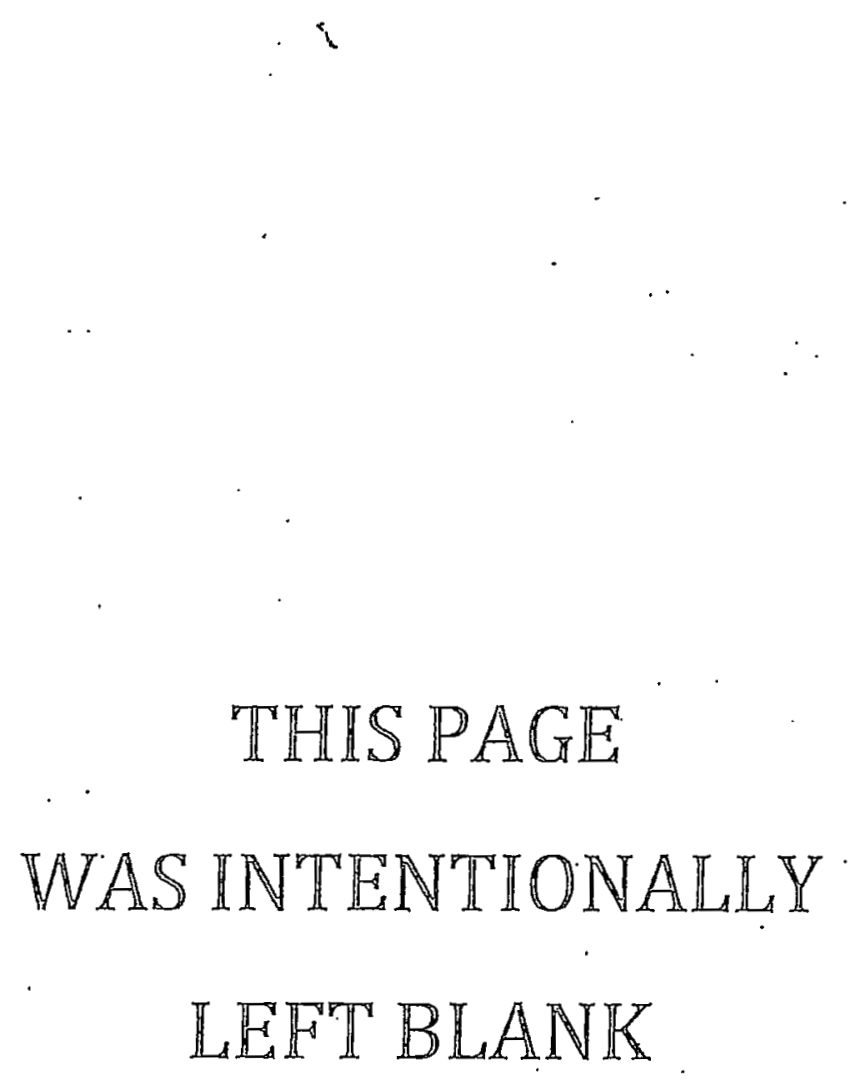


The U. S. Department of Energy, Office of Environment, Office of Environmental Assessments, is conducting a project entitled Technology Assessment of Solar Energy (TASE) Systems, to evaluate the range of potential environmental, health, and socioeconomic consequences of rapid, large-scale commercialization of solar. technologies. The goal of this project is to identify and analyze both the positive and negative effects of solar technology deployment. The project will provide a basis for avoiding potential problems and for grasping opportunities during the transition to solar energy in the $U$. S.

Massive solar development will force major increases in the use of those raw materials needed to make solar system components. Along with this increased resource consumption and production will come associated pollution. In addition, rapid solar energy development may mean significant secondary or unplanned changes in institutions and lifestyles as the nation moves toward greater use of solar energy systems. The TASE project is designed to provide a quantitative analysis of the direct and indirect effects of solar energy use. In so doing; it will help define an environmentally acceptable solar future.

This report is an element of the TASE Solar Technology Characterization Series. We would like to express our appreciation to Terry Surles of the Argonne National Laboratory for his efforts in preparing this document.

Dr. Gregory J. D'Alessio

TASE Project Director

Technology Assessments Division

Dr. Robert $P$. Blaunstein, Manager

Conservation, Solar, and Geothermal Programs

Technology Assessments Division 


\section{THIS PAGE}

\section{WAS INTENTIONALLY \\ LEFT BLANK}


TABLE OF CONTENTS

Page

ABSTRACT . . . . . . . . . . . . . . . . . . . . . . . . . 1

1 THE PRODUCTION OF ETHANOL BY CORN FERMENTATION . . . . . . . . . . . . 1

1.1 INTRODUCTION. . . . . . . . . . . . . . . . . . . . . 1

1.1.1 General System Description . . . . . . . . . . . . . . 1

1.1.2 Resource Distribution. . . . . . . . . . . . . . . 2

1.2 THE MODEL SYSTEM. . . . . . . . . . . . . . . . . . . . . 3

1.2.1 Description. . . . . . . . . . . . . . . . . 3

1.2 .2 Design Basis....................... 5

1.2.3 Energy and Material Flows. . . . . . . . . . . . . . . 7

1.2.4 Equipment and Process Development. . . . . . . . . . . . 9

1.2 .5 Site Location. . . . . . . . . . . . . . . . . . 10

1.3 ENVIRONMENTAL DATA. . . . . . . . . . . . . . . . . 10

1.3.1 General Soil Effects................... 10

1.3.2 Operating Residuals. . . . . . . . . . . . . . . 11

1.3 .3 Land Requirements. . . . . . . . . . . . . . 13

1.3 .4 Water Requirements . . . . . . . . . . . . . . . 13

1.3.5 Collection, Transportation and Handling. . . . . . . . . 13

1.3.6 Construction-Related Residuals . . . . . . . . . . . 15

1.4 ECONOMIC DATA . . . . . . . . . . . . . . . . . . . . . . 15

1.4.1 Capital Costs. . . . . . . . . . . . . . . . 15

1.4 .2 Operating Costs. . . . . . . . . . . . . . . . 16

1.5 SUMMARY OF FINDINGS .. . . . . . . . . . . . . . . . . 17

2 ETHANOL FROM CORN AND WHEAT RESIDUES . . . . . . . . . . . . . . . . . 19

2.1 INTRODUCTION. . . . . . . . . . . . . . . . . . . . . . 19

2.1.1 General Systems Description. . . . . . . . . . . . 19

2.1.2 Resource Distribution. . . . . . . . . . . . . . . 20

2.2 MODEL SYSTEM FOR ACID KYDROLYSIS UF CORN RESIDUE. . . . . . . . . 20

2.2.1. Description. ... . . . . . . . . . . . . . . . . 20

2.2.2 Energy and Material Flows for the Two-Stage
Acid Hydrolysis. . . . . . . . . . . . . . 23

2.3 MODEL SYSTEM FOR THE ENZYMATIC HYDROLYSIS OF WHEAT STRAW. . . • . 24

2.3.1 Description. . . . . . . . . . . . . . . . . . 24

2.3.2 Energy and Material Flows. . . . . . . . . . . . . 26

2.4 ENVIRONMENTAL DATA. . . . . . . . . . . . . . . . . . . . 26

2.4.1 General Soil Effects. . . . . . . . . . . . . . 26

2.4.2 Operating Residuals. . . . . . . . . . . . . . . 27

2.4.3 Land Requirements. . . . . . . . . . . . . . . . . 28

2.4.4 Water Requirements . . . . . . . . . . . . . . . 28 
TABLE OF CONTENTS (Cont'd)

$\underline{\text { Page }}$

2.5 ECONOMIC DATA . . . . . . . . . . . . . . . . . 29

2.5.1 Capital Costs. . . . . . . . . . . . . . . . . . 29

2.5.2 Operating and Maintenance Costs. . . . . . . . . . . 29

2.6 SUMMARY OF FINDINGS . . . . . . . . . . . . . . . . . . . 31

3 ALCOHOLS FROM WOOD . . . . . . . . . . . . . . . . . . . . . . 33

3.1 INTRODUCTION. . . . . . . . . . . . . . . . . . 33

3.1.1 General Description. . . . . . . . . . . . . . . 33

3.1,2 Resource Distribution. . . . . . . . . . . . . . 33

3.2 . MODEL EYSTEM - MFTHANOL FROM WOOD . . . . . . . . . . . . . 34

3.2.1 Description. . . . . . . . . . . . . . . . . $3 / 1$

3.2.2 Energy and Material Flows. . . . . . . . . . . . . 35

3.3 MODEL SYSTEM - ETHANUL FKUM WOOD. . . . . . . . . . . . . . . 36

3.3.1 Description. . . . . . . . . . . . . . . . 36

3.3.2 Energy and Material Flows. . . . . . . . . . . . 37

3.4 ENVIRONMENTAL DATA. . . . . . . . . . . . . . . . . . . . . . . 37

3.4.1 Environmental Consequences of Wood Utilization . . . . . . 37

3.4.2 Land Requirements. . . . . . . . . . . . . . . . 38

3.4.3 Water Requirements . . . . . . . . . . . . . . . 38

3.4.4 Operating Residuals. . . . . . . . . . . . . . . 39

3.5 ECONOMIC DATA . . . . . . . . . . . . . . . . . . . . . 41

3.5.1 Capital Costs. ................... . 41

3.5.2 Operating and Maintenance Costs. . . . . . . . . . . . 41

3.6 SUMMARY OF FINDINGS . . . . . . . . . . . . . . . . . . . 41

REFERENCES. . . . . . . . . . . . . . . . . . . . . 4 45

BIBLIOGRAPHY. . . . . . . . . . . . . . . . . . . . . . 47 


\section{LIST OF TABLES :A':}

No.

Title

$\underline{\text { Page }}$

1.1 Materials Required for a Model Plant with Capacity of 20

Million Gallons per Year. . . . . . . . . . . . . . . . . . . . . . 7

1.2 Material and Energy Flows for a Corn Fêrmentation Plant

with Capacity of 20 Million Gallons of Ethanol per Year . . . . . . 8

1.3 Residuals for Production of Ethanol from 25,000

Bushels (700 Tons) of Corn Per Day. . . . . . . . . . . . . . 12

1.4 Water and Land Requirements of a Model Plant with Capacity.

of 20 Million Gallons per Year. . . . . . . . . . . . . . . . . . . . 14

1.5 Grain Handling Residuals from 25,000 Bushels

(700 Tons) of Corn Per Day. . . . . . . . . . . . . . . . . . 15

1.6 Capital Costs for Model Plant Processing 20 Million

Gallons of Anhydrous Ethanol from Corn. . . . . . . . . . . . . . . 16

1.7 Estimated Operating Costs for Grain Alcohol Production. . . . . . . 17

2.1 Corn and Residue Production and Energy Value of Residues:

Three Midwestern States and U.S., 1976. . . . . . . . . . . . . . . 21

2.2 Wheat and Residue Production and Energy Value of

Residues: Six States and U.S., 1976. • . . . . . . . . . . . . . 21

2.3 Material and Energy Flows for Two-Stage Acid Hydrolysis

of Corn Stover in a Plant with Capacity of 25 Million

Gallons of Ethanol per Year . . . . . . . . . . . . . . . . . 24

2.4 Material Requirements for Enzymatic Hydrolysis of

Wheat straw... ....................... . 27

2.5 Estimated Emissions for $\mathrm{C}_{6}$ Sugar Production by the Tsao

Process and for Ethanol Production. . . . . . . . . . . . . . . 28

2.6 Estimated Emissions for $\mathrm{C}_{6}$ Sugar Production by Enzymatic

Hydrolysis of wheat Straw . . . . . . . . . . . . . . . . . 29

2.7 Estimated Cost of Plant Facilities for Production of

$\mathrm{C}_{6}$ Sugar from Corn Stover by the Tsao Process . . . . . . . . . . . 30

2.8 Estimated Cost of Plant Facilities for Production of

$\mathrm{C}_{6}$ Sugar by Enzymatic Hydrolysis of Wheat Straw . . . . . . . . . . 30

2.9 Estimated Operating Costs for Tsao Hydrolysis Process and Combined Ethanol Plant. . . . . . . . . . . . . . . . . . . . . 31

2.10 Estimated Uperating Costs for Enzymatic Hydrolysis of Wheat Straw . . . . . . . . . . . . . . . . . . . . 32

3.1 Material and Energy Flows for Production of Methanol from Wood. . . . . . . . . . . . . . . . . . . 36

3.2 Material and Energy Flows for Production of Ethanol
from Wood . . . . . . . . . . . . . . . . . . . . . . . . 38

3.3 Residuals from Production of Methanol from Wood . . . . . . . . . . 39

3.4 Residuals from Production of Ethanol from Wood. . . . . . . . . . . 40 


\section{LIST OF TABLES (Cont'd)}

No.

3.5 Capital Costs for Facilities Producing Methanol from Wood by Gasification and Chemical Synthesis . . . . . . . . . . . .

3.6 Capital Costs for Facilities Producing Ethanol by Acid Hydrolysis and Fermentation .

3.7 Operating and Maintenance Costs for the Production of Methanol from. Wood. . . . . . . . . . . . . . . . . . .

3.8 Operating and Maintenance Costs for Production of

\section{LIST OF FIGURES}

No.

1.1 Production of Ethanol by Corn Fermentation . . . . . . . . . . . . . 4

1.2 Theoretical Energy Cycle for Ethanol Production by Corn Fermentation. . . . . . . . . . . . . . . . . . . . . . . . 10

2.1 Two-Stage Acid Hydrolysis of Corn Stover . . . . . . . . . . . . . . 22

2.2 Ethanol Production frop $\mathfrak{C}_{6}$ Sugar Solution. . . . . . . . . . . . . . 24

2.3 Enzymatic Hydrolysis of Wheat Straw. . . . . . . . . . . . . . 25

3.1 Derivation of Methanol from Wood . . . . . . . . . . . . . . . . . 34

3.2 Derivation of Ethanol from Wood. . . . . . . . . . . . . . . . . 37 


\section{ALCOHOL PRODUCTION FROM AGRICULTURAL AND FORESTRY RESIDUES}

by

L. Dale,* R. Opilla, * and T. Surles

ABSTRACT

A variety of carbohydrate sources can be used as raw material for the production of ethanol. Section 1 is a review of technologies available for the production of ethanol from whole corn. Particular emphasis is placed on the environmental aspects of the process, including land utilization and possible air and water pollutants. Suggestions are made for technological changes intended to improve the economics of the process as well as to reduce some of the pollution from by-product disposal.

Ethanol may be derived from renewable cellulosic substances by either enzymatic or acid hydrolysis of cellulose to sugar, followed by conventional fermentation and distillation. Section 2 is a review of the use of two agricultural residues -- corn stover (field stalks remaining after harvest) and straw from wheat crops -- as a cellulosic feedstock. Two processes have been evaluated with regard to environmental impact -- a two-stage acid process developed by G.T. Tsao of Purdue University and an enzymatic process based on the laboratory findings of C.R. Wilke of the University of California, Berkeley.

Section 3 deals with the environmental residuals expected from the manufacture of methyl and ethyl alcohols from woody biomass. The methanol is produced in a gasification process, whereas ethanol is produced by hydrolysis and fermentation processes similar to those used to derive ethanol from cellulosic materials.

\section{THE PRODUCTION OF ETHANOL BY CORN FERMENTATION}

\subsection{INTRODUCTION}

\subsubsection{General System Description}

Ethanol may be obtained from any carbohydrate source such as starch in corn and other grains. The production of 190-proof ethanol, and ultimately anhydroue ethanol, from corn is similar to the ancient process of manufacturing beverage alcohol from grains. Malt (germinated barley) is a source of the enzymes diastase and maltase, which hydrolyze the grain starch into simple 
sugars, a process called 'saccharification. These sugars are, in turn, fermented into alcohol. Enzymes áre also produced commercially by fungal or bacterial processes, which can be substituted for malt-derived enzymes.

Diastase and fungal enzymes work well with starches but are not effective with cellulose, a carbohydrate and a principal ingredient in agricultural residues such as corn cobs, corn stalks, and wheat straw. The use of cellulose as a raw material for the production of fermentable sugars will be discussed in Sec. 2 .

\subsubsection{Resource Distribution}

Researchers at MITRE Corporationl havc catimated that nearly 12 billion gallons of ethanol would be required to produce a $10 \%$-alcohol gasoline blend by the year 200n. That amnunt is 60 Limcy the present U.S. production of industrial ethanol, 1 and if it were to be produced from corn alone, over two-thirds of the present U.S. corn crop would be consumed. ${ }^{2}$

Assuming an average yield of 100 bushels per acre and an ethanol yield of $2-1 / 2$ gallons per bushel, ${ }^{3}$ production of this amount of alcohol would require 48 million acres of corn. Researchers at Batelle-Columbus Laboratories have estimated 4 that perhaps an additional 20 million acres could be added to the U.S. corn production capacity if a critical need should arise.

It has been suggested that instead of growing additional corn especially for alcohol production, the corn presently grown for cattle, swine, and poultry feed be diverted, at least in part, to the production of alcohol. Dried distillers' grain, consisting of spent corn with all the original protein, fiber, and oil, is a by-product of the grain alcohol process and is used as an animal feed. Even if it is not practical to replace all of the feed corn with distillers' grains, a portion of the latter could be allocated to the production of ethyl alcohol. Other potentially useful raw materials, discussed in the next section, are the corn residues of husks, cobs, and stalks. Although the technology is still in the laboratory stage, the energy potential of producing alcohol from cellulosic residues is even greater than that of producing alcohol from corn--approximately 50 million Btu per acre for the residue and 38 million Btu for the corn. 3

On the basis of the foregoing, we estimate that six billion gallons of ethanol can be produced from corn by the year 2000. This amount represents about one-half of the ethanol required for a $10 \%$ gasohol blend. The balance may be derived from other sources of carbohydrates such as agricultural residues.

An important consideration in the production of large volumes of alcohol from corn is the source of enzymes for hydrolysis. Traditionally, the enzyme used for the conversion of starch to fermentable sugaro has been derived from malt. There are, however, certain problems associated with the production and use of this enzyme. First, it has a relatively low yield of enzymes per pound of malt, unlike other enzymes that are now commercially

available. Second, the quality of the enzyme produced from malt is quite variable and is dependent on the varieties of barley, malting procedures, 
use of gibberellic acid, and the drying and roasting steps following sprouting. On the other hand, the commercial enzymes produced either from bacterial or fungal systems are highly. purified to produce large quantities of enzymes having a very high degree of specificity for the desired reaction in the starch hydrolysis. For these reasons, commercial enzymes are preferred. As far as the authors know, sufficient amounts of commercially produced enzyme can be made available from Novo in Denmark and the U.S. or Miles Laboratories in the U.S. to handle near-term needs for power alcohol. The ability to construct the fermentation plants required for the production of additional enzymes certainly would take no longer than is required to bring al1 future alcohol capacity into existence. Therefore, substantial problems with supply of adequate enzyme for hydrolysis of starch to sugar are not expected.

Enzymes degrade the starch molecule in a structurally specific manner, resulting in the production of dextrose only until the enzyme reaches a branch in the starch molecule, whereupon a dissaccharide is produced. Under the best conditions, a yield of dextrose on the order of $98.5 \%$ can be achieved.

The hydrolysis can also be performed with mineral or organic acid and occurs randomly, resulting in saccharides of various degrees of polymerization, as well as products of degradation as the dextrose molecule continues to be attacked by the acid ions in the solution. The maximum yield of fermentable sugar by acid-catalyzed hydrolysis is probably on the order of $85 \%$. Therefore, little consideration is likely to be given to acid hydrolysis since current practice indicates that the most cost-effective way to produce fermentable sugars from starch is by the use of enzymes.

It is, however, fairly common to speed up the relatively slow rate of the enzyme reaction by utilizing a small quantity of acid, which reduces viscosity but has little material impact on the yield of dextrose. Consequently, the most effective way to produce dextrose from starch is to use a very dilute acid solution (approximately. 0.1 normal solution) followed by the use of the commercially produced enzymes, Alpha-Amylase and Gluc-Amylase, which complete the conversion of the higher degrees of polymerized starch fractions to the monosaccharide.

\subsection{THE MODEL SYSTEM}

\subsubsection{Description}

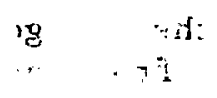

The production of alcohol from corn is a stepwise process (Fig. 1.1). The corn is cleaned with a series of vibrating screens that sift out foreign materials. Air jets remove dust and light material, and separators remove magnetic substances. The grain is then stored until required.

In the first step of the process, milling of the grain, the outer protective hull of cellulose is broken, exposing the starch within the corn kernel. Impact or hammer mills are generally used in this step.

Conversion of starch to sugar is termed mashing in the distillery industry. This step involves the gelatinization and hydrolysis of the starch to simple sugars in the presence of the appropriate enzyme. In order for the 


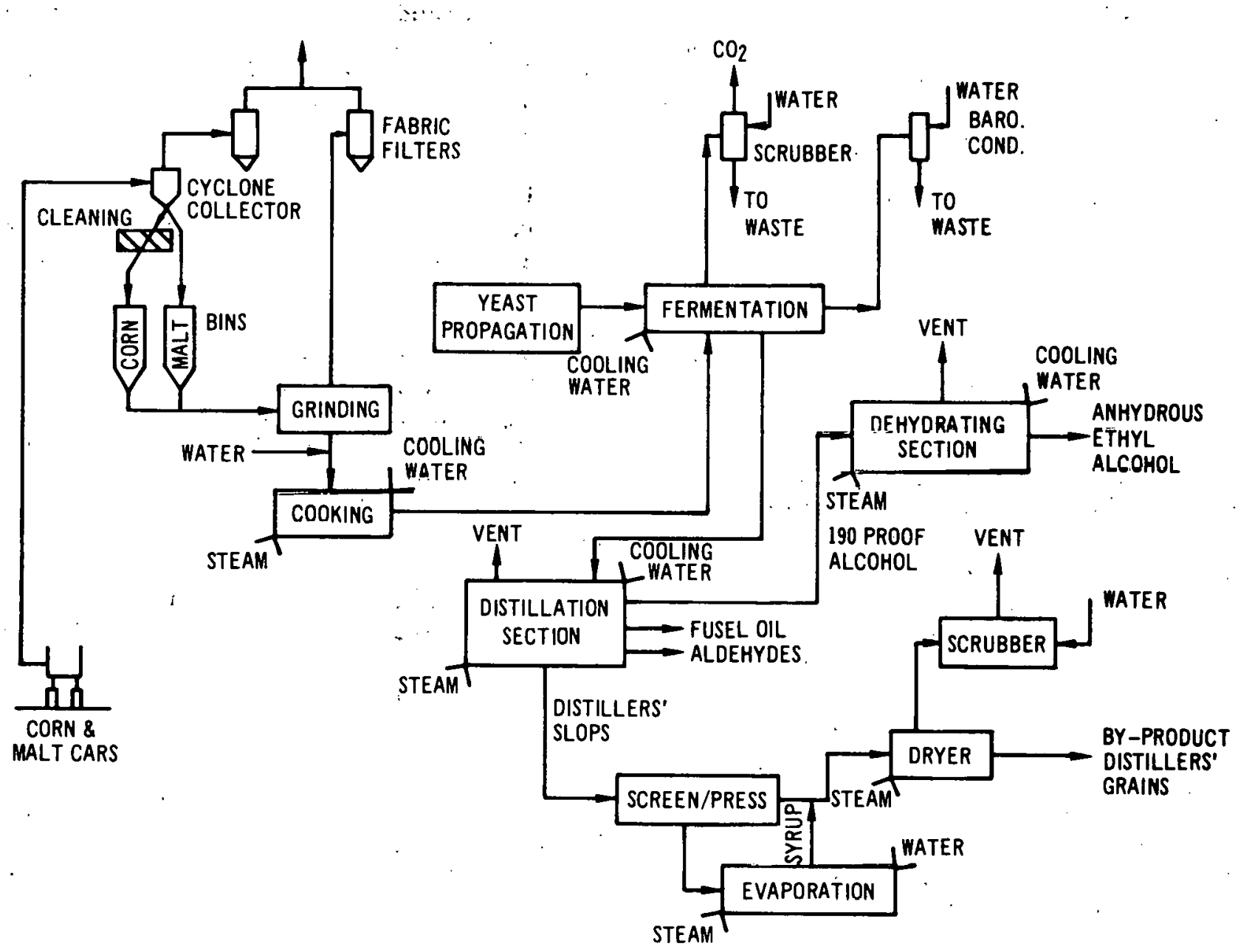

Fig. 1.1. The Production of Ethanol by Corn Fermentation

hydrolysis to occur, the starch must be gelatinized and liquefied by the combination of heat and water. Gelatinization of corn starch cannot occur except in he presence of water over a temperature range of about 156 to $176^{\circ} \mathrm{F}$. Until the starch is gelatinized, hydrolysis is very difficult to perform. The hydrolysis step requires 20 to, 35 gallons of water per bushel of corn and may be carried out with enzymes or under pressure with mineral acid, either in batches or in a continuous process. This reaction step may be represented as follows:

$$
\begin{aligned}
& \left(\mathrm{C}_{6} \mathrm{H}_{10} \mathrm{O}_{5}\right) \mathrm{n}+\mathrm{nH}_{2} \mathrm{O} \\
& (\text { Starch }+ \text { Water })
\end{aligned}
$$

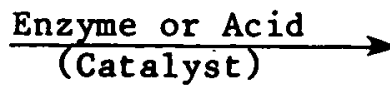

Fermentation, the next step in the process, involves the conversion of fermentable sugars into nearly. equal. weights of ethanol and carbon diuxide as follows :

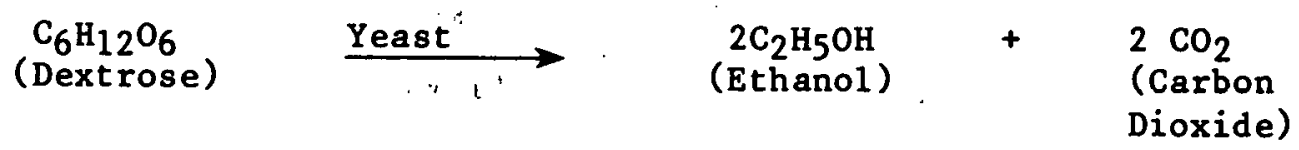


Fermentation requires two to five days depending on operating temperatures and takes place in a group of vats arranged to permit the filling, fermenting, emptying, cleaning, and sterilization required for the process. Fermentation generates heat, and heat removal. is important to control the process at $90-95^{\circ} \mathrm{F}$ where reactions proceed quickly and safely.

Yeast required for the fermentation is normally produced by a separate process and is normally not reused extensively in fermentation since yeast characteristics change, or contamination can occur, which would result in the production of other materials besides ethanol.

Distillation involves the separation and concentration of the alcoholic products of yeast fermentation. The basic continuous system consists of a "beer" column separating a mixture containing the 6-12\% alcohol. Additional columns may be added for flexibility, including an aldehyde-concentrating column and a fusel-oil-stripping column. All of this equipment is used to produce the various materials in the most concentrated form, thereby making water available for reuse in the process.

Distillation will produce an alcohol of $95 \%$ concentration by volume (190-proof alcohol). For fuel-grade ethanol, further concentration is required to yield an anhydrous alcohol with a purity in excess of $99 \%+$ to avoid the separation of water that occurs when $95 \%$ alcohol is mixed with gasoline, 3 but researchers are attempting to find additives that would prevent such separation.

Extractive distillation is used to dehydrate $95 \%$ ethanol to anhydrous ethano1. The azeotrope of ethanol and water is broken by adding benzene to form a ternary mixture allowing separation of the ethanol. The benzene is retrieved and recycled.

Bottoms from the "beer" column called "stillage" or "distillers" slop" contain a suspension of spent grain and dilute'alcohol solution. Solids are removed from the alcohol solution and are concentrated by screening or centrifuging, pressing, and drying to produce dried distillers' grains. The extracted liquid is concentrated with multiple-effect evaporators to a syrup containing approximately $35 \%$ dissolved solids. This syrup is then mixed with the dehydrated solids and the mixture is dried in a rotary dryer. Dried distillers' grains represent about 6.5 pounds of by-product per gallon of alcohol produced and, as stated earlier, are important to the overall economics of grain alcohol production.

\subsubsection{Design Basis}

David et al. of Development Planning and Research Associates (DPRA) have conducted an extensive study on optimum plant size. 5 Conversion, ethanol transportation, grain transportation, and by-product distribution costs were examined over a range of plant sizes from $10^{\prime}$ to 120 million gallons per year. Conversion costs were found to increase with increasing plant size and especially so for plant capacities above 40 million gallons per year.

A model plant size of 20 million gallons of ethanol per year was selected for this report for several reasons. D.L. Miller ${ }^{3}$ estimates that a 
20-million gallon plant is the maximum cost-efficient size because of the unit sizes available for equipment. Of the equipment components that go into an ethanol manufacturing plant, the most expensive unit is the distillation assembly for separating alcohol from roughly $7 \%$ aqueous solution to produce anhydrous alcohol. This assembly consists of an alcohol stripping column, an alcohol rectifying column, and an azeotropic distillation column to convert 95\% alcohol to anhydrous alcohol. Under normal shop fabrication conditions and shipping requirements, a column of approximately 12-ft, 6-in. diameter and 60-ft length $c$ an be shop assembled, shipped intact, and installed at the facility without field fabrication. A column of these dimensions would allow production of approximately 20 million gallons of alcohol per year.

Other systems -- grain handling, starch gelatinization and saccharification, and fermenters -- all require multiple units which, if shop fabricated, would have dimensions of approximately 12-ft, 6-in. diameter and 18 24-ft. height. Again, the limitation on the diameter results from shipping requirements.

The main rationale for using shop-fabricated equipment is to maintain hlgh quality as well as low production cost. All of the equipment designed for a plant of capacity larger than 20 million gallons could be shop fabricated in sections match-marked for field erection, but this would cost more and be subject to less rigorous quality control than could be obtained under shop-controlled conditions.

Inasmuch as the columns required for the distillation of alcohol are infinitely variable between $1-i n$. diameter and 12-ft, 6-in. diameter, plants of sizes up to 20 million gallons are not restricted by a modular approach. Once the 20 million gallon maximum is exceeded, the columns must be field erected, or multiples of the module are required. It would appear that the most economical plant capacities range from very small to 20 million gallons per year, with increments of 20 million gallons thereafter.

If five 20-million-gallon alcohol plants were completed by 1985, with an additional facility growth rate of $20 \%$ per year; approximately 150 plants would be in operation by the year 2000, producing six billion gallons per year. This is the amount of alcohol previously determined to be practical on the basis of corn availability in the. United States.

Finally, the bubk of the literature and engineering studies on alcohol plants concerns, 20 -millition gallon plants, thereby providing a good technology base for this program.

\section{Materials of Construction}

Non-sparking materials of construction are recommended for the grainhandling system. These materials would. include bronze or aluminum for conveying equipment working against galvanized steel troughs and ducts. Although some erosion is possible, the major consideration is explosiveness of the grain dust. The material probably best suited for gelatinization and saccharification of starch is glass-coated mild steel. In the event that this is 
Table 1.1. Materials Required for a Model Plant with Capacity of 20 Million Gallons Per Year

\begin{tabular}{|c|c|c|c|c|}
\hline Component & $\begin{array}{l}\text { Carbon } \\
\text { Steel } \\
\text { (tons) }\end{array}$ & $\begin{array}{l}\text { Stainless } \\
\text { Steel } \\
\text { (tons) }\end{array}$ & $\begin{array}{c}\text { Alumi num } \\
\text { (tons) }\end{array}$ & $\begin{array}{c}\text { Concrete } \\
(y d s)\end{array}$ \\
\hline Equipment & 2600 & 450 & 11 & -- \\
\hline Building & 1600 & -- & -- & 4800 \\
\hline Total & 4200 & 450 & 11 & 4800 \\
\hline
\end{tabular}

not available, stainless steel type 316 with extra-low carbon would probably be the best material for the starch hydrolysis reactors.

The fermenters could be fabricated from epoxy-coated mild steel to hold down the cost. For the distillation equipment, the ethanol stripping and rectifying column should be fabricated from stainless steel type 304 , whereas the azeotropic distillation could be performed in a mild steel column. If a gasoline or benzene stripper is included in the plant, it could probably also be made of mild steel.

All ductwork passing dry materials should be fabricated from galvanized steel. Any wet solids handled in the system should pass through ducts made of stainless steel type 304 .

All piping in the wet end should be stainless steel type 304, Schedule 5 pipe or tubing to provide ease of cleaning and a good sanitary material construction. Table 1.1 summarizes material requirements for a model plant.

\subsubsection{Energy and Material Flows}

Material requirements and a resultant process energy distribution for the selected model are given in Table 1.2. The total input of fuel energy is approximately 136,000 Btu per gallon of ethanol produced, 5 which is a common amount of energy input for the beverage alcohol industry. The required energy is roughly distributed into approximately one-third for the front end (grinding and cooking), one-third for distillation of the alcohol and onethird for drying of the spent grain. ${ }^{3}$ Note that there is some debate on the necessity of the drying process. This energy is supplied by fossil fuels, preferably coal or coal-generated electricity, and does not include the energy content of the corn.

Beverage alcohol at 190 proof has a higher heating value of about 80,000 Btu per gallon. When upgraded by extractive distillation, the heating value increases to $84,000 \mathrm{Btu}$ per gallon.

It is apparent that considerably more fuel -- 136,000 Btu -- is required by this process than is produced in the alcohol. However, the overriding issue is that the process converts a solid fuel (coal) to a liquid fuel 
that may be used directly to produce gasohol for transportation. Improvements in design, including the prudent use of heat recovery systems, can be made in the traditional processes, resulting in the reduction of fuel requirements to less than 80,000 Btu per gallon of end product.

Anhydrous alcohol production, which includes the added step of extractive distillation, is not energy-intensive. The energy balance lists the fuel input at 5,000 Btu per gallon for dehydration, although some manufacturers of equipment are claiming that no additional energy is required for this step.

Materials entering and leaving the process are also listed in Table 1.2. As stated earlier, carbon dioxide is a by-product nearly equal in weight

Table 1.2 Material and Energy Flows for a Corn Fermentation Plant with Capacity of 20 Million Gallons of Ethanol per Year.

\begin{tabular}{|c|c|c|}
\hline System Variable & Material Flow & Energy Flow. \\
\hline $\begin{array}{l}\text { Fuel Required } \\
\text { e } 82 \% \text { Boiler Efficiency } \\
\text { Process Water } \\
\text { Boiler \& Cooling } \\
\text { Water Makeup } \\
\text { Total } \\
\text { Additional Plant Chemicals, } \\
\text { Caustic Soda }(50 \% \text { wt }) \\
\text { Sulfuric } \Lambda \text { cid }\left(66^{\circ} \mathrm{Be}\right) \\
\text { Phnsphate }\left(\mathrm{Naj}_{3} \mathrm{PO}_{4}\right) \\
\text { Sodium Sulfite } \\
\text { Corrosion Inhibitor } \\
\text { Biocide } \\
\text { Chlorine }\end{array}$ & $\begin{array}{l}19.5 \text { tons of coal/hour } \\
750 \mathrm{gpm} \\
600 \mathrm{gpm} \\
1,350 \mathrm{gpm}(32 \mathrm{gal} / \mathrm{gal} \mathrm{EtOH}) \\
\text { Annual Use: }{ }^{2} \\
70,000 \mathrm{gal} \\
67,000 \mathrm{gal} \\
10,0001 \mathrm{~h} \\
2,0001 \mathrm{~b} \\
7,0001 \mathrm{~b} \\
8,0001 \mathrm{~b} \\
6,0001 \mathrm{~b}\end{array}$ & $\begin{array}{r}8.4 \times 10^{9} \mathrm{Btu} / \mathrm{day} \\
5.1 \times 10^{9} \mathrm{Btu} / \mathrm{day} \\
32,000 \mathrm{Btu} / \mathrm{gal} \text { EtOH } \\
0 \\
52,000 \mathrm{Btu} / \mathrm{gal} \text { EtOH } \\
5,000 \mathrm{Btu} / \mathrm{gal} \text { EtOH } \\
42,000 \mathrm{Btu} / \mathrm{gal} \text { EtOH } \\
5,000 \mathrm{Btu} / \mathrm{gal} \text { EtOH } \\
136,000 \mathrm{Btu} / \mathrm{gal} \text { EtOH }\end{array}$ \\
\hline
\end{tabular}

$\mathbf{a}_{\text {By-product. }}$

bSource: Dwight Miller, U.S. Dept. of Agriculture, Peoria, Illinois, personal communication. 
to the desired product and is wasted by venting to the atmosphere. Utilization of the large volumes of carbon dioxide prepared by this process is not economical.

\subsubsection{Equipment and Process Development}

A review of the traditional process revealed the possibility of several changes that could improve overall process economics. Careful attention to the water balance used in the plant design could reduce evaporation requirements substantially. Separation of the protein, fiber, and oil from the hydrolyzed starch prior to fermentation could reduce the volume of fermentation equipment as well as simplify operation of the "beer" column.

Continuous fermentation of grain sugars is generally considered an improvement in alcohol production. This innovation, as practiced in the fermentation of wine and sugar syrups, could reduce corn sugar fermentation time considerably, thereby lowering production costs and capital investment. However, alcohol from grain is an energy-intensive process; continuous fermentation would not result in energy savings and may even result in lower alcohol yields than those obtained with batch techniques.

Vacuum fermentation coupled with a continuous process that allows alcohol vapors to be continuously withdrawn from the fermenters could replace the "beer" column, resulting in energy savings. However, the cost of equipment for this method is high, and energy is required to produce the vacuum. Techniques under investigation to improve concentration of ethanol to anhydrous ethanol include reverse osmosis, molecular sieves, solvent extraction, and freeze concentration of the alcohol-water mixture. Freeze concentration and clarification of hydrolysate prior to fermentation could produce substantial energy reduction.

Available yeast strains are limited to the production of solutions containing approximately $12 \%$ alcohol. New strains may be isolated and adapted to survive at greater alcohol strengths, thereby allowing a more efficient process with higher alcohol yields.

Utilization of stillage or distillers' grains in wet form would substantially decrease energy requirements (by roughly one-third). Depending on plant location, the distillers' grains could be pumped to nearby hog or cattle feed lots and utilized immediately as feed. The manure produced by the hogs and cattle could be transferred to anaerobic fermenters to produce methane and $\mathrm{CO}_{2} \cdot 6$ The methane, augmented by other fuels, could be burned in the steam-generation facility of the ethanol plant. Manure residue still contains nearly all of its original nitrogen after anaerobic digestion and could serve to fertilize a nearby corn crop. In addition, meat packing and processing plants could be constructed in the same vicinity. These packing and processing plants could utilize some of the carbon dioxide for cryogenic freezing in meat-processing operations. A theoretical corn-alcohol-feedlot cyclic energy system is depicted in Figure 1.2. 


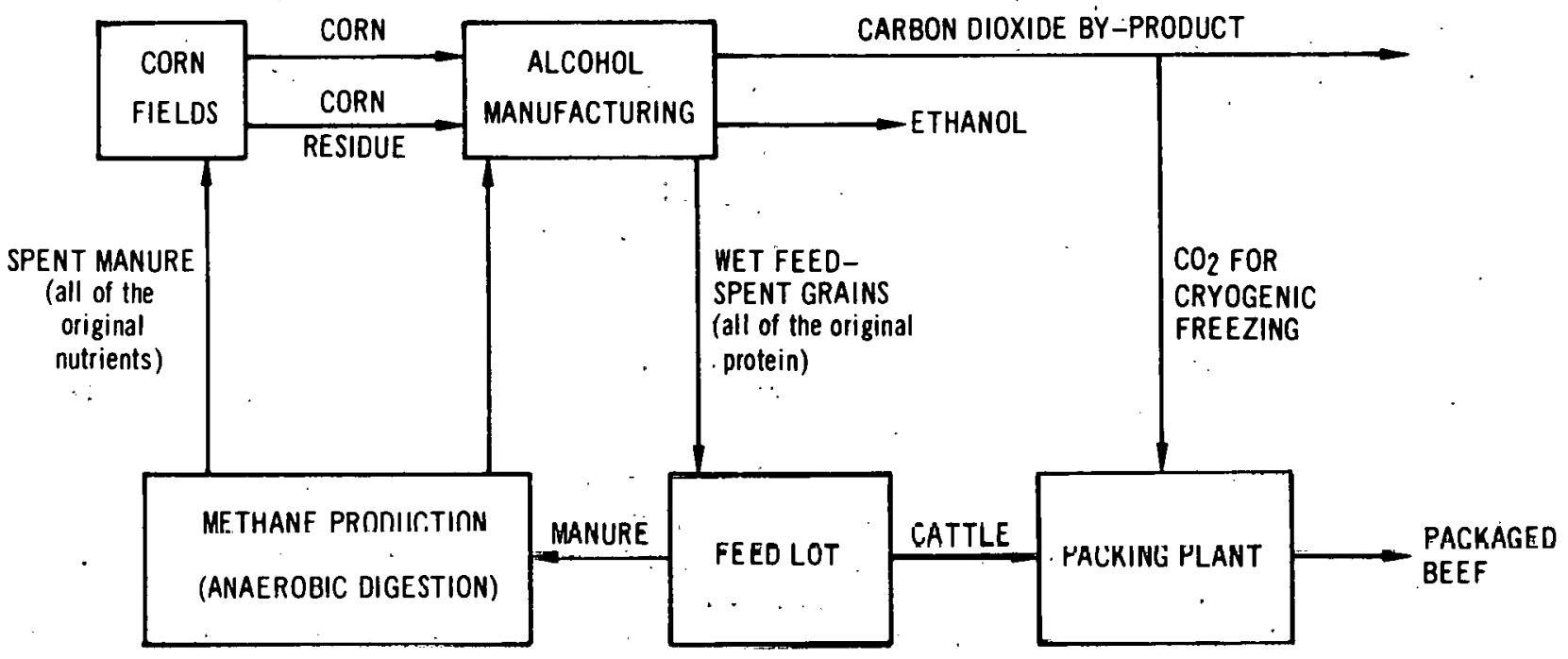

Fig. 1.2. Theoretical Energy Cycle for Ethanol

Production by Corn Fermentation

\subsubsection{Site Location}

The best locations for ethanol production facilities would be in areas close to a corn supply as well as to abundant coal sources. If these two factors are the major considerations, then a North Central location in the United states would be indicated. If serious consideration is given to the use of feed lots for disposing of distillers' grains, then a more western location would be preferred -- probably midway between the many coal deposits available in the Rocky Mountains and the Corn Belt -- Ohio, Indiana, Illinois, Iowa, and Nebraska.

Siting of ethanol producing plants in Nebraska and Colorado would also make available alternative sources of carbohydrate such as wheat, milo maize, and grain sorghum.

\subsection{ENVIRONMENTAL DATA}

\section{3 .1 General Soil Effects}

In comparison to many other crops, the production of corn requires large amounts of nitrogen. To prevent loss of nitrogen from the soil, which would have dramatic effects on corn yields, rotation with legume crops or utilization of anhydrous ammonia is required.' Anhydrous ammonia is produced from petroleum by-products, and this use of petroleum has not been taken into account in any of the energy considerations discussed thus far.

The practice of rotating fields between corn and soybeans has been utilized to a very large degree in the corn belt to reduce the amount of ammonia or other nitrogen-based fertilizers required by corn. With the ex- 
pansion of more and more acreage to produce corn to meet the alcohol demand, the impact of the additional alternative crop(s) on the marketplace will have to be considered. Actually, any crop that can fixate nitrogen can be rotated with corn provided that the growing habits of those crops are similar to the growing needs of corn. Other legumes are better at nitrogen fixation than soybeans, but the comparability of the seasonal requirements of these crops with those of corn may be the determining factor.

\subsubsection{Operating Residuals}

When corn starch is converted to alcohol by hydrolysis and fermentation, approximately equal weights of ethanol and carbon dioxide are formed in the process (about $6.5 \mathrm{lbs}$ of each per gallon of product). The $\mathrm{CO}_{2}$ is driven from the mash by the chemical reactions within the fermenter. This vat will often be closed and under. pressure so that it is a relatively easy matter to scrub the off gas and remove nearly al.1 of the very soluble alcohols. This $\mathrm{CO}_{2}$ is almost invariably vented to the atmosphere, although some have attempted to recover and reuse or market the gas. Potential uses include liquefaction for use in the beverage industry or to provide an inert atmosphere in grain storage facilities. In most cases, the market for $\mathrm{CO}_{2}$ will not be strong enough to warrant recovery for sale. Therefore, the $\mathrm{CO}_{2}$ driven from the process is reported as an operating residual in Table 1.3. However, this should not be a significant environmental concern -- an alcohol plant of 20-million-gallon capacity discharges 197 tons of $\mathrm{CO}_{2}$ per day whereas an average power plant discharges many thousands of tons of $\mathrm{CO}_{2}$ per day.

Little information exists regarding the organics associated with this exit gas. Some writers have suggested an arbitrary $1 \% 10$ ss of product (ethanol). Producers state that total loss of product in the entire plant is considerably less than $1 \% .{ }^{3 *}$ In this report, a loss of $0.25 \%$ of product will be assumed. Odor is occasionally mentioned as an environmental problem in residential areas, but modern closed fermenters should avoid this with wel1-designed and maintained equipment.

Aside from power plant emissions, the largest emissions of particulates occur in the front end and back end of the plant, that is, from grain elevators, screening, and grinding of corn in the beginning, or during the drying and handling of spent distillers' grains in the by-product area. Emissions are generally controlled by gas cyclones followed by fabric-bag filters. The EPA reports an emission factor of 12.0 bs for corn receiving, handling, and cleaning per ton of corn processed (uncontrolled emissions). Data were not available with regard to stillage drying; thus, we also assumed 12 lbs of emissions per ton of corn dried. The total uncontrolled particulate emissions -- 24 lbs per ton of corn processed -- was assumed to be controlled to $90 \%$-removal with a residual of 2.4 lbs per ton of corn. Air emissions associated with the burning of coal to produce steam are also listed in Table 1.3.

\footnotetext{
*Distillery Plant A, personal communication.
} 
Table 1.3. Residuals for Production of Ethanol from 25,000 Bushels (700 Tons) of Corn per Day

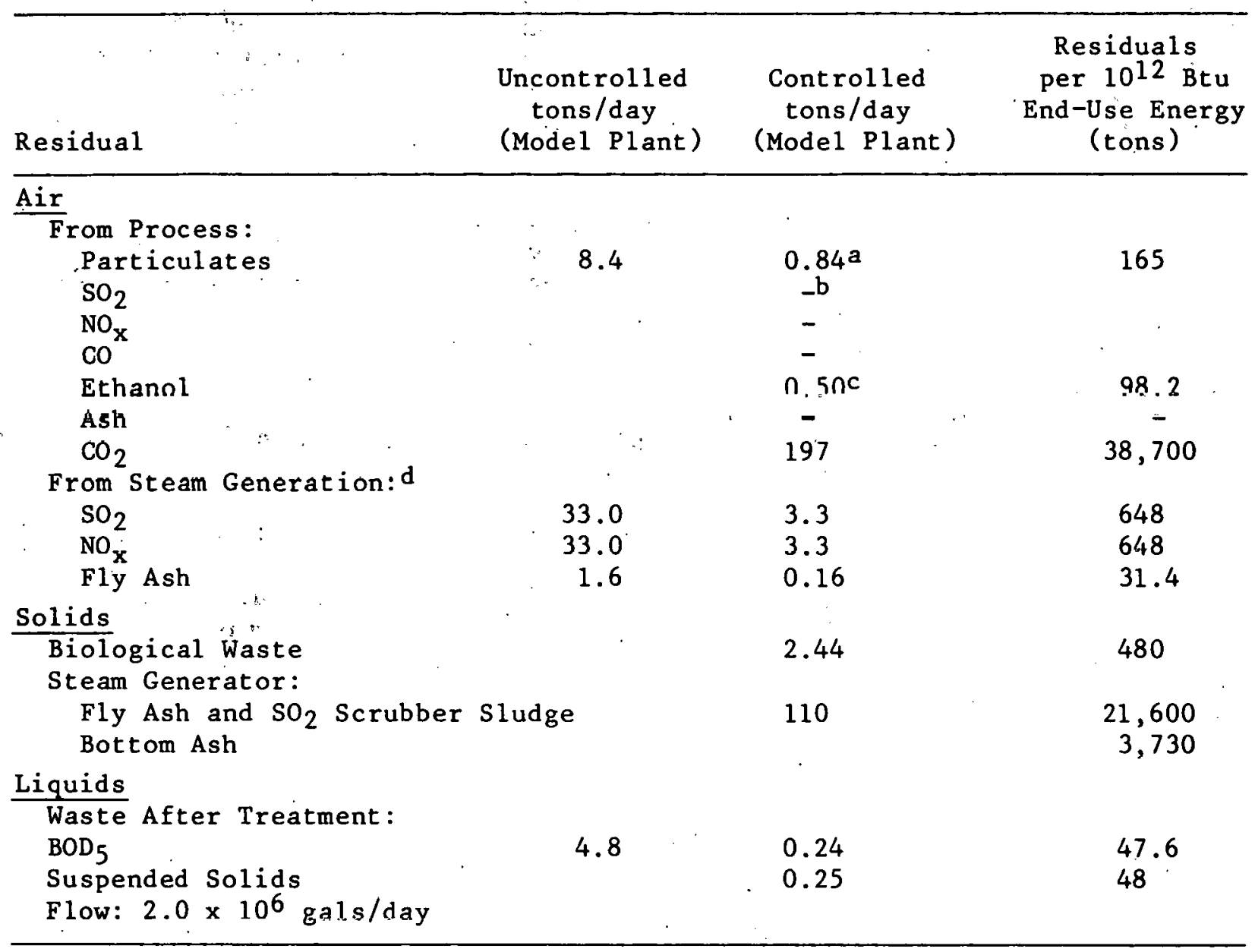

a. 2.4 lbs per ton of corn.

$\mathrm{b}_{\text {Neg }} 1$ igible amount.

$c_{0.25 \%}$ of ethanọ 1 production.

$\mathrm{d}_{\text {NSPS }}$ etandards as sumed:

$\mathrm{SO}_{2}$ controlled to $0.6 \mathrm{lbs} / 10^{6} \mathrm{Btu}$ fuel,

Fly ash controlled to $0.031 \mathrm{bs} / 10^{6} \mathrm{Btu}$ fuel,

NO $x$ controlled to $0.6 \mathrm{lbs} / 10^{6} \mathrm{Btu}$ fuel. Source: U.S. EPA, Region V, personal communication.

Waste water sources in the ethanol plant contain, basically, dissolved biodegradable alcohols. These BOD $_{5}$ - bearing waters emanate from the following areas:

1. Spent stillage recovery (evaporator condensate)

2. Flash cooler (mildly contaminated)

3. Barometric condensers (vacuum source for fermenters)

4. Washings from fermenters

5. Acid and caustic wastes (neutralized) 
The waste water should be treatable with conventional activated sludge methods. Proper design should result in approximately $95 \%$ removal of $\mathrm{BOD}_{5}$. The amount of raw waste might range from approximately 12 to 55 gallons per gallon of product and the waste may contain contaminants equivalent to 0.12 to 0.17 lbs of BOD $_{5}$ per gallon of ethanol product. With a waste plant capable of $95 \%$ removal of residuals, the effluent will amount to about 0.008 lbs per gallon of ethanol product or 47.6 tons of BOD $_{5}$ per $10^{12} \mathrm{Btu}$ of end-use energy. Waste treatment plant effluent will contain a like amount of suspended solids.

The main source of solid waste is biological growth associated with secondary treatment of the liquid waste previously mentioned. Approximately $0.5 \mathrm{lb}$ of excess activated sludge can be expected for each pound of BOD $_{5}$ removed.8 Assuming the $r$ aw waste contains $0.171 \mathrm{~b} \mathrm{BOD}_{5}$ per gallon of product ethanol, then $95 \%$ removal corresponds to 961 tons BOD $_{5}$ removed per $10^{12}$ Btu produced. Excess waste, then, will amount to 480 tons per $10^{12} \mathrm{Btu}$. (Note: a food to mass ratio of 0.3 has been assumed with a sludge retention time of eight days. Extended aeration or aerobic digestion would considerably reduce excess activated sludge solids).

Scrubbing of stack gas from the steam generator will also contribute collected fly ash and $\mathrm{SO}_{2}$ scrubber sludges to solid waste. Tonnage will vary widely depending on the type of coal burned and the nature of the $\mathrm{SO}_{2}-$ removal system. If properly dehydrated, these sludge cakes may be landfilled without causing significant pollution problems.

\section{$1.3: 3$ Land Requirements}

The 1 and requirements for the plant proper as well as a waste treatment plant have been estimated to be approximately 80 acres for production of 20 million gallons of ethanol per year.

\section{$1,3,4$ Water Requirements}

As Table 1.2 shows, the total fresh water requirements for a 20-million gallon plant are 1,350 $\mathrm{gpm}$ : $750 \mathrm{gpm}$ for the process and $600 \mathrm{gpm}$ for the boiler and cooling-tower. This represents 32 gallons of water per gallon of ethanol produced, or $3.8 \times 10^{8}$ gallons of water per $10^{12}$ Btu of end-use energy. It should be emphasized that water use can exceed this figure depending on the nature of the operation, reaching 50-60 gallons per gallon of product. Table 1.4 summarizes water and land requirements of a model plant.

\section{1:3.5 Collection, Transportation, and Handling}

Fugitive dust as a result of increased corn cropping for energy feedstocks will be of some concern. Harvesting is, however, normally practiced in October or November, well after the normally arid summer months, so that dusting rates are lessened. Little is known of the effects of fugitive dust on habitats surrounding croplands. Studies have shown, however, that road dust, which may be assumed to be similar in nature to that from croplands, changes light absorptivity, which thus influences photosynthesis and productivity. ${ }^{9}$ 
Table 1.4. Water and Land Requirements of a Model Plant with Capacity of 20 Million Gallons Per Year

\begin{tabular}{|c|c|c|c|}
\hline$\cdots$ & 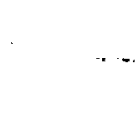 & $\begin{array}{r}\text { Quantity } \\
\text { For Model }\end{array}$ & $\begin{array}{c}\text { Quantity per } \\
10^{12} \text { Btu } \\
\text { End-Use Energy }\end{array}$ \\
\hline $\begin{array}{l}\text { Water } \\
\text { Land } \\
\text { Corn Crop }\end{array}$ & $\cdots$ & $\begin{array}{c}1,350 \text { gpm } \\
80 \text { acres } \\
80,000 \text { acres }\end{array}$ & $\begin{array}{l}3.8 \times 10^{8} \mathrm{gal} \\
47.5 \text { acres } / 10^{12} \mathrm{Btu} / \mathrm{yr} \\
47,534 \text { acres }\end{array}$ \\
\hline
\end{tabular}

a Based on 100 bushels of corn per acre.

Pesticides and fertilizers associated with the crops and, therefore, a part of the fugitive dust produced during crop collection, are often toxic materials affecting the, health of terrestrial ecosystems, leading to rhanges in trophic dynamics. The rate of chemical loss into terrestrial ecosystems is unknown as are the effects of varying concentrations of residuals on the terrain. Dust is of minor importance with regard to ecological changes. The associated chemicals could, however, have a significant impact. The use of less toxic chemicals will diminish this problem, but intensive corn production demanding larger fertilizer inputs may counteract the benefits.

Grain handling involves a number of steps that will generate dust, including initial receipt of the grain at a terminal elevator, delivery, storage, and, finally, milling. These steps include unloading (receiving), drying, cleaning, and conveyor operations. Many elevators use control devices such as cyclones and, more recently, fabric filters. 7 Some sources in grain elevators present control problems in containment of emissions. Probably the most difficult sources to control, because of large flow rate and high moisture content of the exhaust gases, are the dryers. Continuously vacuumed screen systems are available for reducing dryer. emissions and have been applied at several facilities. Particulate emissions are shown in Table 1.5 .

Transporting the grain to the processing facility will not produce significant amount of pollutants, particularly if the alcohol plant is located in the corn belt. For example, the model alcohol plant $\left(20 \times 10^{6} \mathrm{gal} / \mathrm{yr}\right)$ studied for this work requires 80,000 acres of corn to sustain production. Total acreage devoted to corn in the Illinois, Indiana, and Iowa area is about 31 million acres (Table 2.1). Total land area in these states is about 149,000 square miles or 95 million acres. Corn intensity is, then, about $33 \%$. If, for the sake of argument, we assume that $20 \%$ of this corn is allotted to alcohol manufacture, the crop intensity associated with such use would be about $7 \%$. Therefore, the total land mass yielding 80,000 acres of corn for alcohol would be, on the average, 1.15 million acres, or a radius of about 25 miles. Assuming 10-ton grain trucks, the 700 tons per day of corn required for a $20 \times 10^{6}$ gal/yr plant could be transported with only 2400 truck miles per day, less than $0.0002 \%$ of the nation's vehicle mileage. 
Table 1.5. Grain Handing Residuals from 25,000

Bushels ( 700 tons) of Corn per Day

\begin{tabular}{|c|c|c|c|}
\hline \multirow[t]{2}{*}{. } & \multicolumn{3}{|c|}{ Emissions } \\
\hline & $\begin{array}{l}\text { Uncontrolled } \\
(1 \mathrm{~b} / \text { ton })\end{array}$ & $\begin{array}{l}\text { Controlled } \\
\text { (1b/ton) }\end{array}$ & $\begin{array}{l}\text { per } 10^{12} \text { Btu } \\
\text { End-Use Energy } \\
\text { (tons) }\end{array}$ \\
\hline \multicolumn{4}{|l|}{ Dry Corn Milling } \\
\hline $\begin{array}{l}\text { Receiving } \\
\text { Drying } \\
\text { Precleaning \& Handling } \\
\text { Cleaning House }\end{array}$ & $\begin{array}{l}1.0 \\
0.5 \\
5.0 \\
6.0\end{array}$ & $\begin{array}{l}0.10 \\
0.05 \\
0.50 \\
0.60\end{array}$ & \\
\hline Total & 12.5 & 1.25 & 85.8 \\
\hline \multicolumn{4}{|l|}{ Wet Corn Milling } \\
\hline $\begin{array}{l}\text { Receiving } \\
\text { Handling } \\
\text { Cleaning }\end{array}$ & $\begin{array}{l}1.0 \\
5.0 \\
6.0\end{array}$ & $\begin{array}{l}0.10 \\
0.50 \\
0.60\end{array}$ & \\
\hline Total & 12.0 & 1.20 & 82.3 \\
\hline
\end{tabular}

\subsubsection{Construction-Related Residuals}

Total plant area under heavy construction is unlikely to be more than 3 to 4 acres. This land will generally be depressed from surrounding terrain and erosion with runoff will not be a problem unless the plant is built on the side of a hill. Fugitive dusting can occur during heavy construction but should not be a factor for more than 2 to 3 weeks during the construction phase and only if this phase occurs in the dry season. Even then, workers will voluntarily water down the site daily to avoid uncomfortable working conditions.

Contractors allow about $0.3 \%$ of construction costs for complete clean-up of refuse and debris after completion. This refuse consists of shorts of pipe, wire, structural members, and wood, and it will be sorted into barrels and sold to metal reclaimers and scavengers. Construction residuals are not tabulated since they are not a significant concern.

\subsection{ECONOMIC DATA}

\subsubsection{Capital Costs}

Expenditures for an ethanol plant of the model size considered, 20 million gallon annual capacity, are well documented.5 Capital costs for a facility of this size are summarized in Table 1.6. The total of $\$ 27,645,000$ is in 1972 dollars. "Engineering" cost consists of $7.5 \%$ for fengineering detail, $1 \%$ for procurement, and $1.5 \%$ for construction management. As plant replicas are designed, these costs will be reduced. 
Table 1.6. Capital Costs for Model Plant Processing 20 Million Gallons of Anhydrous Ethanol

from Corn (1972 Dollars $\times 10^{3}$ )

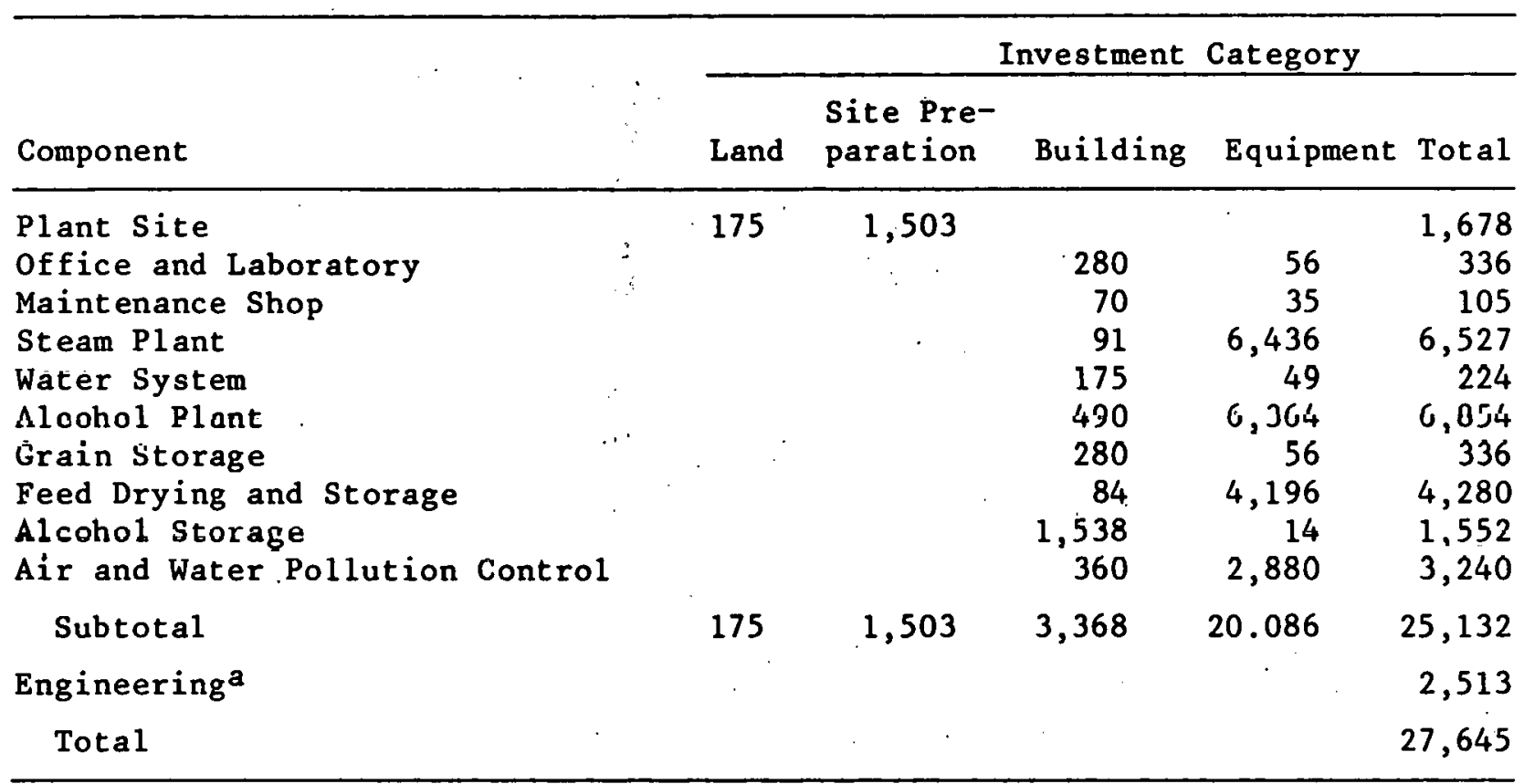

Source: Ref. 5. Deflated from 1977 to 1972 dollars by factor of 1.43 .

ancludes procurement, engineering details, and construction management.

As indicated earlier, it is suggested that a modular approach for plant sizes greater than 20 million gallons. per year, e.g., 40 or 60 million gallons of annual capacity. There will be a small savings in "duplicate" engineering, as mentioned above. Costs will, then, increase less than linearly with the number of modules. An exponential factor of 0.9 is suggested for scaling up by module. For example, a two module plant (40 million gallons per year) will cost 20.9 or 1.87 times the 20 million gallon size; similarly, the three-module or 60 million gallon plant will cost 30.9 or 2.69 times the 20 million gallon facility.

For plants smaller than 20 million gallons, a premium will be paid for equipment smaller than optimum and for one-time engineering. We suggest a "scale-down" factor of 0.80 (exponential). For example, a 10-million gallon plant costs $(10 / 20) 0.8$ or 0.57 times 28 much as the 20 million gallon module.

\subsubsection{Operating Costs}

The price of whole corn is a factor of concern in the production of ethanol from whole corn. A bushel of corn contains approximately 34 pounds of starch, and approximately two pounds of starch are required to produce one pound of alcohol. If the current price of whole corn is $\$ 2.50$ per bushe1, the raw material cost (neglecting by-product credits). amounts to about $15 \notin$ per pound of alcohol produced or about $96 \notin$ per gallon. This does not include 
any other operating costs such as direct labor, utilities, maintenance, or depreciation. Operating costs for the model plant are presented in Table 1.7 .

\subsection{SUMMARY OF FINDINGS}

A review of the available information shows that existing technology and probable improvements can make the production of ethanol from corn technically feasible. Environmental considerations will not impose any major restraints on the utilization of the process. However, the high cost of raw materials in this process is likely to provide incentive for research and development of other methods for producing ethanol or methanol.

Table 1.7. Estimated Operating Costs for Grain Alcohol Productiona (1972 dollars)

\begin{tabular}{lcc}
\hline Component & $10^{6}$ Dollars/yr & $\begin{array}{c}\text { Dollars/gal } \\
\text { Ethanol }\end{array}$ \\
\hline Chemicalsb & 0.120 & 0.006 \\
Maintenance materials & 0.483 & 0.024 \\
Labor (operating, maintenance, \& support) & 1.311 & 0.065 \\
Utilities (includes fuel)b & 2.620 & 0.131 \\
G and A Property taxes \& insurance & 0.441 & 0.022 \\
Plant depreciation (20 yr) & 0.552 & 0.028 \\
$\quad$ Cost without raw materials & 1.380 & 0.069 \\
$\quad$ Cost of whole corn & 6.907 & 0.345 \\
$\quad$ Total operating cost & 13.420 & 0.671 \\
\end{tabular}

aplant capacity is 20 million gallons per year. Plant cost is $\$ 27.6$ million.

bSource: Ref. 5. 1977 dollars are deflated by a factor of 1.43. Other factors as a percent of capital cost are: maintenance materials, $1.75 \%$; maintenance 1 abor, $1.75 \%$; operating labor with support, $3.00 \%$; $G$ and $A, 1.60 \%$; property tax \& insurance, $2.00 \%$. 


\section{THIS PAGE}

\section{WAS INTENTIONALLY \\ LEFT BLANK}




\section{ETHANOL FROM CORN AND WHEAT RESIDUES}

\subsection{INTRODUCTION}

Ethanol may be derived from renewable cellulosic substances by either enzymatic or acid hydrolysis of cellulose to sugar, followed by conventional fermentation and distillation. This section deals with two agricultural residues -- corn stover (field stalks remaining after harvest) and straw from wheat crops -- that can be used as cellulosic feedstock. Two ethanol production processes have been evaluated with regard to environmental impact, a two-stage acid.process developed by G.T. Tsao of Purdue University and an enzymatic process based on the laboratory findings of C.R. Wilke of the University of California, Berkeley.

\subsubsection{General Systems Description}

Useful liquid fuel or fuel-supplements may be produced by the "bioconversion" or fermentation of any carbohydrate (sugars or starches) to alcohol. The starches in grain as sugar sources have been discussed in the first section of this report. The fermentation and distillation of these carbohydrates to produce ethanol have been practiced for centuries. However, competition for these crops is keenly felt, since they provide food, animal feed, and fiber, which bring a higher financial return. This section deals with the cellulosic agricultural residues, specifically corn residue (stalks, cobs, and husks) and wheat residue (straw), as potential sources of energy convertible to ethanol.

Cellulosic solids contain three major ingredients: cellulose, hemicellulose and lignin. 10 Corn cobs, for example, contain $40 \%$; $36 \%$, and $16 \%$ of these materials, respectively. Cellulose is of the glucose family, and hemicellulose is usually a polymer of pentoses, hexoses, and sugar acids. Lignin is polyphenolic and has a high heating value. If separated and concentrated, lignin may be a valuable source of secondary fuel. However, at present, it is more valuable as a source of other chemicals. Research on this subject is under way at the University of Washington. The celluloses may be hydrolyzed to sugar, which may then be fermenced to alcohol.

Hemicellulose is easily hydrolyzed under moderate reaction conditions using acids or enzymes. On the other hand, cellulose is resistant to breakdown into sugars because of its strong crystalline structure and because the lignin tends to surround and seal the cellulose fiber. Acids can attack both cellulose and lignin; however, because of the strong crystalline structure, only strong acids work well, which results in high chemical costs (for the hydrolyzing acid and subsequent neutralizing alkali). Strong acids also tend to degrade glucose, llus lowering the ethanol yield. Specific enzymes called cellulases can catalyze conversion of cellulose to glucose but, unfortunately, have no effect on the lignin. However, if the cellulosic materials are finely ground (smaller than 400 mesh), the crystal surfaces are exposed and subject to hydrolytic attack by the cellulases. Tricoderma vimide celluloses are the most common thus tested. Unfortunately, fine grinding is energy intensive and, in addition, an ultra-fine feedstock will result in an extrafine waste that will be more difficult to dewater. 
Hydrolysis of celluiose is still being studied in the laboratory and should be commercialized in the near future. Two hypothetical processes are presented in this report -- a two-stage acid process for converting cellulose in stover (stalks remaining after harvest) suggested by G.T. Tsao of Purdue 10 and $S$. Barnett of the University of Rhode Island; and an enzymatic hydrolysis of wheat straw based on data from C.R. Wilkell of the Unviersity of California at Berkeley. The hypothetical plants developed by the Stanford Research Institute (SRI)12,13 were used in the study reported here.

\subsubsection{Resource Distribution ,}

According to a MITRE study, 14 approximately 322 million tons (dry basis) of crop residues are produced annually. The greatest acreage (147 million acres) is planted in corn and wheat divided about 50/50 in each crop. The total energy equivalent in the residue is roughly 50 million Btu per acre for corn stover and $30 \mathrm{million}$ for wheat straw. The calculated total potential heat energy in these two residues is a staggering 6000 trillion Btu per year. ${ }^{3}$ About $86 \%$ of these residues is considered collectable, but much of it will not be used for fuel but for purposes such as soil conditioning, erosion control, animal feed, and animal bedding. The SRI studyl2 suggests that perhaps $10 \%$ to $15 \%$ could be available for ethanol production in many areas without competing against other uses. The MITRE study14 indicated that $60 \%$ of available residues is produced in the East North Central and West North Central census regions.

The three-state "corn belt" of Illinois, Iowa, and Indiana accounts for $50 \%$ of total U.S. corn production. Table 2.1 details the grain and residue production and tocal residuc cnergy equivalent in these three states. Table 2.2 contains production figures for wheat grown in a six-stace arta that accounts for 43 million acres of the nation's 71 million acres of wheat.

Additional studies are needed to accuracely pledict available agricultural residue, taking into consideration the impact of crop residue removal. One study 15 identifies eight agricultural regions in the U.S. (Arkansas, California, Georgia, Illinois, Nebraska/Iowa, Oregon, Texas and Kansas) and lists. crop tonnages and corresponding available crop residue tonnages for cach reginn. Availability of residues is estimated on the basis of type of crop, soil type, climate, disease problems, and the cultural system, but these estimates are somewhat arbitrary.

\subsection{MODEL SYETEM FOR ACTD HYDROLYSIS OF CORN RESIDUE}

\section{2 .1 Description}

As stated carlier, the model system selected for the study reported here is a two-stage acid hydrolysis of corn stover. 13 In this process cellulose is converted into sugars, followed by a conventional fermentation of sugar to ethanol. Tsao's process increases cellulose reactivity, thereby greatly improving yield. The hydrolysis section of the hypothetical plant consists of the following three basic steps: 
a) The pentosans, hemicellulose and amorphous cellulose that are readily hydrolyzed are removed in the firststage hydrolysis.

b) Crystalline cellulose is solvated with strong sulfuric acid to break down the structure.

c) Solvated crystalline cellulose is converted to $\mathrm{C}_{6}$ sugars in the second-stage hydrolysis.

Table 2.1. Corn and Residue Production and Energy Value of Residues: Three Midwestern States and U.S., 1976

\begin{tabular}{lcccccc}
\hline Location & $\begin{array}{c}\text { Corn } \\
\text { (bu/ } \\
\text { acre) }\end{array}$ & $\begin{array}{c}\text { Corn } \\
\text { tons/ } \\
\text { acre) }\end{array}$ & $\begin{array}{c}\text { Residue } \\
\text { (tons/ } \\
\text { acre) }\end{array}$ & $\begin{array}{c}\text { Total } \\
\text { Harvested } \\
\text { Acreage } \\
\left(10^{3} \text { acres }\right)\end{array}$ & $\begin{array}{c}\text { Total } \\
\text { Residue } \\
\left(10^{6} \text { tons }\right)\end{array}$ & $\begin{array}{c}\text { Total } \\
\text { Energy } \\
\text { Value } \\
\left(10^{12} \text { Btu }\right.\end{array}$ \\
\hline Illinois & 107.0 & 3.00 & 3.21 & 11,690 & 37.5 & 413.5 \\
Indiana & 110.0 & 3.08 & 3.30 & 6,300 & 20.8 & 229.3 \\
Iowa & 90.0 & 2.70 & 2.89 & 12,750 & 36.8 & 405.8 \\
$\quad$ Total & - & - & - & 30,740 & $95.1 \ldots$ & $1,048.6$ \\
U.S. Total & 87.4 & 2.45 & 2.62 & 71,085 & 186.2 & $2,053.0$ \\
\hline
\end{tabular}

Table 2.2. Wheat and Residue Production and Energy Value of Residues: Six States and U.S., 1976

\begin{tabular}{|c|c|c|c|c|c|c|}
\hline Location & $\begin{array}{l}\text { Wheat } \\
\text { (bu/ } \\
\text { acre) }\end{array}$ & $\begin{array}{l}\text { Wheat } \\
\text { (tons/ } \\
\text { acre) }\end{array}$ & $\begin{array}{c}\text { Residueb } \\
\text { (tons/ } \\
\text { acre) }\end{array}$ & $\begin{array}{c}\text { Total } \\
\text { Harvested } \\
\text { Acreage } \\
\left(10^{3} \text { acres }\right)\end{array}$ & $\begin{array}{c}\text { Total } \\
\text { Residue } \\
\left(10^{6} \text { tons }\right)\end{array}$ & $\begin{array}{c}\text { Total } \\
\text { Energy } \\
\text { Valuec } \\
\left(10^{12} \text { Btu }\right)\end{array}$ \\
\hline Kansas & 30.3 & 0.90 & 2.50 & 11,300 & 27.8 & 301.9 \\
\hline Montana & 30.9 & 0.93 & 2.53 & 5,415 & 13.7 & 148.8 \\
\hline North Dakota & 24.7 & 0.74 & 2.02 & $11,65.5$ & 23.6 & 256.3 \\
\hline Okl ahoma & 24.0 & 0.72 & 1.97 & 6,300 & 12.4 & 134.7 \\
\hline Texas & 22.0 & 0.66 & 1.80 & 4,700 & 8.5 & 92.3 \\
\hline Minnesota & 32.2 & 0.97 & 2.65 & $\therefore \quad 4,056$ & 10.7 & .116 .2 \\
\hline Total & - & - & - & 43,426 & 96.7 & $1,050.2$ \\
\hline U.S. Total & 30.3 & 0.91 & 2.50 & 70,824 & 177.1 & $1,923.3$ \\
\hline
\end{tabular}

a Data from Ref. 16 .

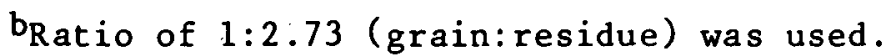

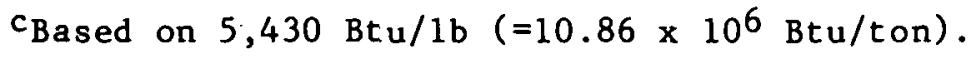




$$
\text { . : }
$$

Figure 2.1 is a simplified flow diagram of this process. Corn stover ground to minus-10 mesh is digested in batches with dilute sulfuric acid for about 50 minutes at $250^{\circ} \mathrm{F}$, under "pressure. After cooling, this suspension is filtered, washed, pressed and dried. Drying is necessary to prevent dilution of the strong acid used in the solvation step. Filtrate containing residual acid is neutralized with lime. Precipitated gypsum is settled, filtered, and disposed of as solid waste, but this is a costly process. Clarified, neutralized. liquid contains $\mathrm{C}_{5}$. sugars and is available for conversion to butanediol or to ethanol. Solvation of the dried material from the first step takes place in a continuous reactor; the acid is strong enough to break down the crystalline cellulose but too weak to dissolve the lignin. Solvated cellulose is reprecipitated by addition of methanol. Solids are separated and washed free of the acid and methanol with centrifuges and filters used in series. The filtrate" (dilute sulfuric acid) serves to hydrolyze the corn stover in the first-stage hydrolysis.

Washed solids with some acid and methanol still adhering to their surfaces are moved to second stage hydrolysis where most of che remaining celluose is converted to a $c 6$ sugar solution. This solution is tiltered, neutralized, and pumped to the ethanol plant. Lignin solids filtered from this solution are transferred to the steam plant to be used. as a fuel supplement. Acid, and methanol are separated by evaporation and recovered for reuse.

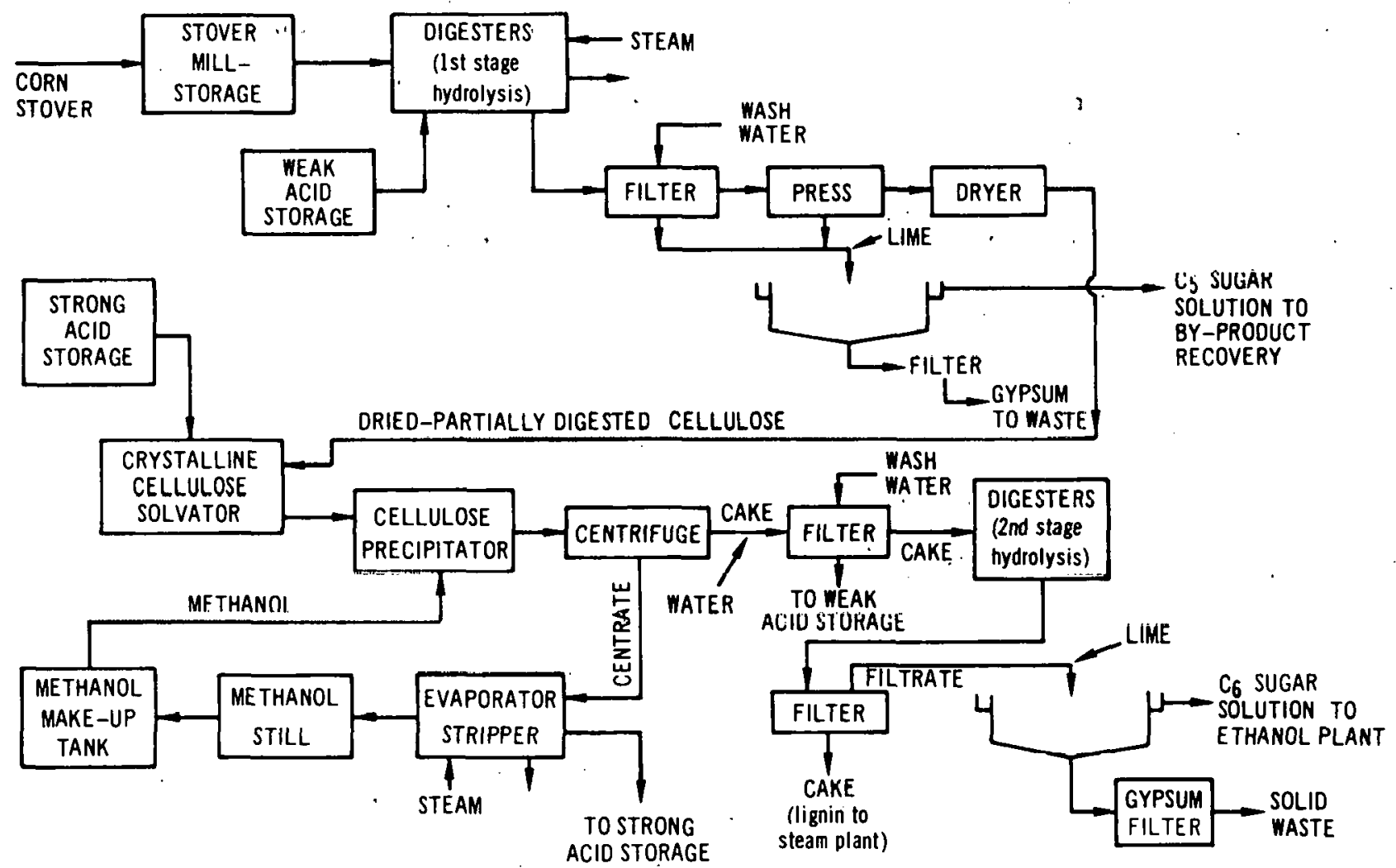

Fig. 2.1. Two-Stage Acid Hydrolysis of Corn Stover 
Fermentation of the $\mathrm{C}_{6}$ sugar solution followed by distillation (schematically shown in Figure 2.2) has been described 12 for a plant processing 500 tons of sugar per day. Although not shown in the schematic, the 190 proof ethanol may be upgraded to 199+ proof by an extractive distillation step described in the corn-to-alcohol section. The $\mathrm{C}_{6}$ sugar solution produced in the hydrolysis plant is more concentrated (14\%) than specified for fermentation $(10.7 \%)$. Therefore, it may not be necessary to include an evaporatorconcentration section at the front end of the fermentation plant. It is important to note, however, that two pounds of sugar yield approximately one pound of ethanol. Therefore, a $14 \%$ sugar solution will yield an alcohol of only $7 \%$ strength at best. Yeast strains are available that would produce an alcohol of up to $11 \%$ or $12 \%$ in the fermentation of sugar. These writers 12 , suggest modifications in the hydrolysis process to strengthen the $\mathrm{C}_{6}$ sugar solution to $20 \%-22 \%$. Tsao's original water balance, in fact, suggested $20 \%$, but this was altered to ensure adequate washing of solids during final filtration. Perhaps, multiple filtration stages with counter-current washing would be in order to maintain solution strength with good wash recovery.

\subsubsection{Energy and Material Flows for the Two-Stage Acid Hydrolysis}

Table 2.3 lists material and energy requirements for an acid hydrolysis plant associated with an ethanol facility with a capacity of 25 million gallons per year. Fuel energy input for the hydrolysis section is partially defrayed by the separation of lignin from corn stover and subsequent burning for steam generation. In fact, this source supplies nearly $60 \%$ of the steam requirement. Total energy input for both process sections (hydrolysis and fermentation/distillation plants) is $10.0 \times 10^{9}$ Btu per day, equivalent to 121,000 Btu per gallon of ethanol produced. This is almost exactly the same energy requirement as that for the corn-to-alcohol process described in Section 1. If anhydrous alcohol were to be synthesized from this plant producing 190 proof ethanol, up to 5000 additional Btu would be required per gallon produced. However, the heating value of the product would, in turn, increase

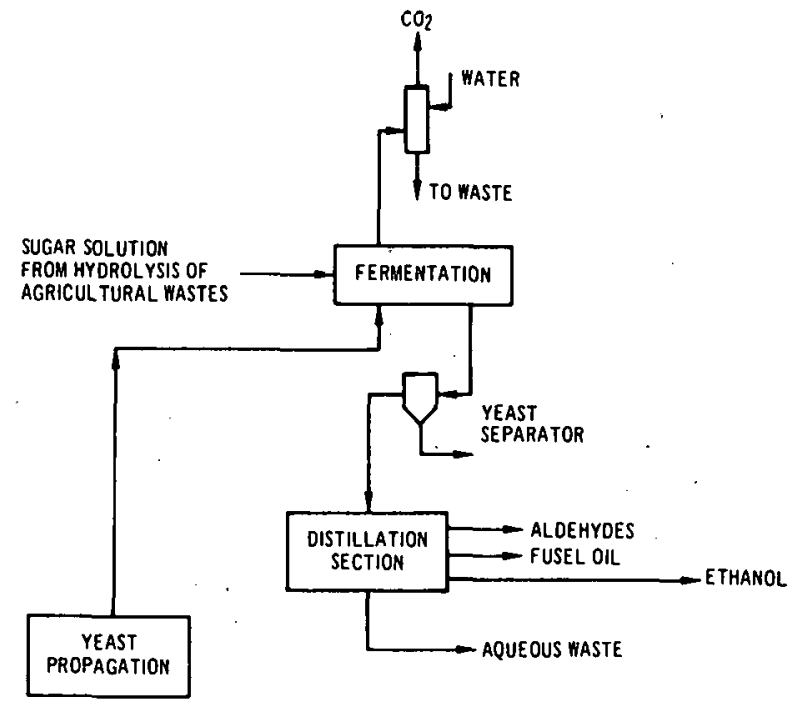

Fig. 2.2. Ethanol Production from $\mathrm{C}_{6}$ Sugar Solution 
Table 2.3.
Haterial and Energy Flows for Two-Stage Acid
city of 25 Million Gallons of Ethanol per Year

\begin{tabular}{|c|c|c|}
\hline System Variable & Material Flow & Energy Flow \\
\hline \multicolumn{3}{|l|}{ Hydrolysis Section } \\
\hline $\begin{array}{l}\text { Corn Stover } \\
\text { Sulfuric Acid } \\
\text { Methanol } \\
\text { lime } \\
\text { Steam a } \\
\text { Fresh WaLer } \\
\text { bal } \\
\text { E'Lelricily (1U4,83L kWh/day) }\end{array}$ & $\begin{array}{c}1,562 \text { dry tons/day } \\
118.9 \text { tons/day } \\
28.1 \text { tons/day } \\
66.5 \text { tons/day } \\
281,510 \mathrm{~b} / \text { hour } \\
1,800 \mathrm{gpm} \\
161.5 \mathrm{tons} / \mathrm{day}\end{array}$ & $\begin{array}{l}3.5 \times 10^{9} \mathrm{Btu} / \mathrm{dayc} \\
1.2 \times 109 \mathrm{Btu} / \mathrm{day} d\end{array}$ \\
\hline \multicolumn{3}{|l|}{ Ethanol Section $^{b}$} \\
\hline $\begin{array}{l}\text { Cooling and Boiler Water Make-up: } \\
\text { Process Water } \\
\text { Electricity }(86,600 \mathrm{kWh} / \text { day }) \\
\text { Steam }\end{array}$ & $\begin{aligned} 700 \mathrm{gpm} \\
0 \mathrm{gpm} \\
143,640 \mathrm{lb} / \text { hour }\end{aligned}$ & $\begin{array}{l}1.0 \times 10^{9} \mathrm{Btu} / \mathrm{day} \mathrm{d} \\
4.3 \times 10^{9} \mathrm{Btu} / \text { day (fue } 1 \text { ) }\end{array}$ \\
\hline $\begin{array}{l}\text { Total Energy Inputs, } \\
\text { Both Plant Sections } \\
\text { (fossil fuel) }\end{array}$ & & $10.0 \times 10^{9} \mathrm{Btu} / \mathrm{day}$ \\
\hline \multicolumn{3}{|l|}{ Sugar Solution } \\
\hline $\begin{array}{l}\text { Sugar } \\
\text { Water }\end{array}$ & $\begin{array}{r}41,6401 \mathrm{~b} / \text { hour } \\
347,519 \mathrm{lb} / \text { hour }\end{array}$ & \\
\hline $\begin{array}{l}\text { Carbon Dioxide } \\
\text { Ethanol ( } 95 \% \text { volume) }\end{array}$ & $\begin{array}{l}290 \text { tons } / \text { day } \\
3,157 \mathrm{ga} 1 / \text { hour }\end{array}$ & $6.06 \times 10^{9} \mathrm{Btu} / \mathrm{day}$ \\
\hline
\end{tabular}

a $166,000 \mathrm{lb} /$ hour steam is generated from the burning of residue with high lignin content. The remaining steam demand is met by burning coal.

bSource: Ref. 12 .

c Includes $82 \%$ boiler efficiency.

dincludes $30 \%$ efficiency of conversion.

from 80,000 to 84,000 Btu per gallon. In addition, as SRI points out, 13 if the fuel value associated with the $\mathrm{C}_{5}$ sugars is taken into account, the heating value of the products exceeds plant fuel (coal) requirements by over $30 \%$.

\subsection{MODEL SYSTEM FOR THE ENZYMATIC HYDROLYSIS OF WHEAT STRAW}

\subsubsection{Description}

Figure 2.3 is a schematic of the theoretical process designed by SRI12 from Wilke's 11 laboratory data. The process consists of four sections described as follows: 


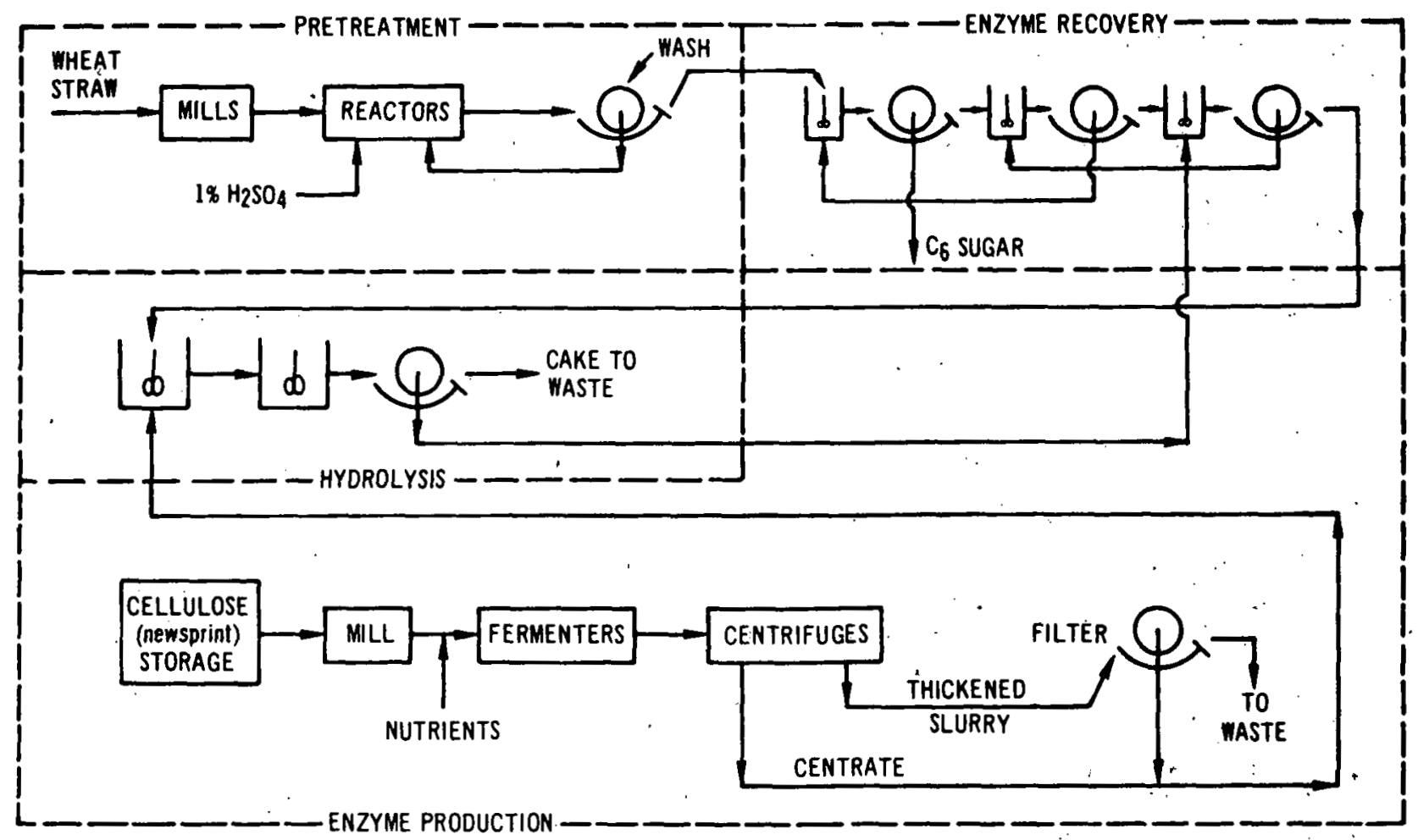

Fig. 2.3. Enzymatic Hydrolysis of Wheat Straw

a) Pretreatment. Milled straw is digested with $1 \%$ sulfuric acid.at $212^{\circ} \mathrm{F}$ for 1.1 hours producing $C_{5}$ sugars, xylose, and arabinose, in solution. The mixture is then fil-. tered, recycling most of the filtrate back to pretreatment and wasting the balance. Wet filter cake containing the cellulosic substrate flows to the enzyme recovery section where it is used to adsorb and recover the enzyme in the sugar solution from the hydrolysis section.

b) Enzyme Recovery. Cake from pretreatment is mixed with hyrolysate and filtered in three counter-current wixerfilter stages. The "strong filtrate" from the first filter stage is the sugar solution-product that flows to the ethanol plant (not shown here but identical to. the ethanol plant shown in Figure 2.2). Cake from the third stage filter flows to the enzymatic hydrolysis section.

c) Hydrolysis. Wet filter cake from the enzyme recovery section is hydrolyzed with a cellulose enzyme solution made from $1 \%$ cellulose (newsprint) slurry containing protease peptone plus urea and other salts. This reaction is carried out continuously in sets of four hydrolyzers in series for a total detention of 40 hours. A $5 \%$ slurry concentration is maintained at $122^{\circ} \mathrm{F}$ and at a pH of 4.8 using citrate solution. Following hydrolysis, the mixture is filtered and 
the solution returns to enzyme recovery. Wet cake containing unhydrolyzed solids contaminated with enzyme is disposed of as a solid waste.

d) Enzyme Production. This reaction is an aerobic fermentation in a series of reactors kept at $86^{\circ} \mathrm{F}$ by refrigeration. Final effluent from the reactor is filtered with the filtrate containing enzyme in solution and is then sent to the hydrolysis section. Wet cake is disposed of as a solid waste.

The sugar solution, which is produced by the facility just described and which flows to an adjacent fermentation plant, contains only $4 \%$ sugar by weight. Therefore, it will be necessary to incorporate a solution concentration section (evaporation with multiple effects) at the front end of the ethanol plant, 12 which will increase the strength of the sugar concentration to $10.7 \%$. The rest of the ethanol plant consists of conventional fermentatinn and distillation processes resulting in a 190-proof product. As stated earlier, alcohol concentration will be roughly half the sugar concentration, so that a $10.7 \%$ sugar solution will result in only $5 \%-5-1 / 2 \%$ alcohol. This is energetically inefficient, and modifications in the water balance of the hydrolysis stage should be considered in order to achieve a sugar concentration of $20 \%-22 \%$.

\subsubsection{Energy and Material Flows}

Table 2.4 ists material and energy flows for the enzymatic hydrolysis of wheat residue. Note that over 3,000 dry tons of straw are required to produce 500 tons of sugar. Only $45 \%$ of the hexosans present are assumed converted to sugar. Hydrolysate flowing to the ethanol plant contains only $4 \%$ sugar by weight in solution so that it would be necessary to preconcentrate the solution before fermentation. The authors of the SRI design 12 were concerned that higher concentrations of solids during hydrolysis might be too thick to keep properly agitated and/or flowing through pipelines. They anticipate that it may be possible to increase the slurry to $7-1 / 2 \%$ by weight, thereby increasing the sugar concentration to $6 \%$. However, coal and water slurries are well agitated and pumped at $50 \%$ by weight and so this may not be a problem. Unless process alterations that result in even higher sugar concentrations are, developed, the ethanol. plant will be heavily penalized for fuel requirements.

\subsection{ENVIRONMENTAL DATA}

\subsubsection{General Soil Effects}

The impact of total or partial removal of agricultural residues on soil has been addressed at length by Harper et al.17 
Table 2.4. Material Requirements for Enzymatic"

Hydrolysis of Wheat Strawa

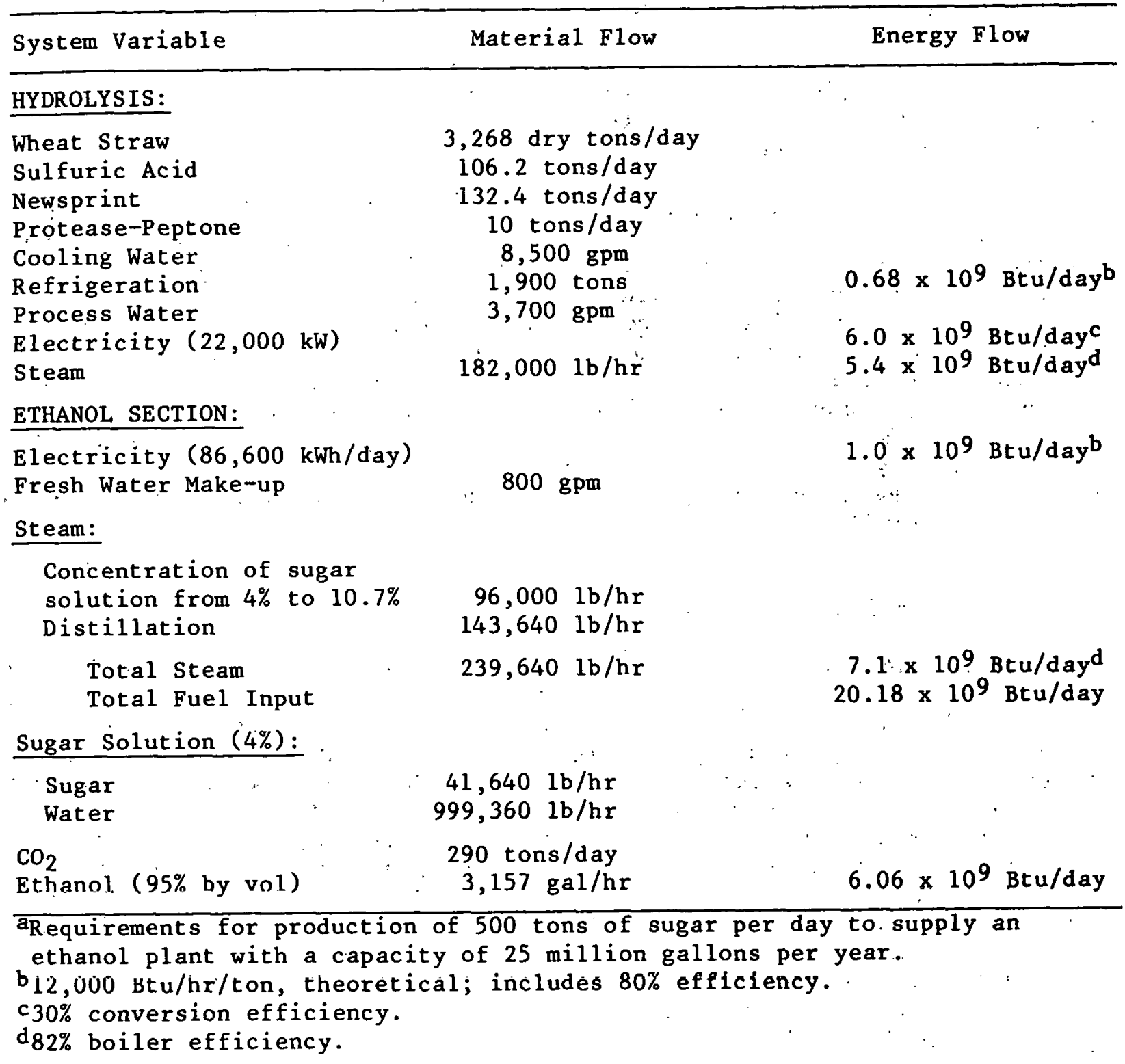

\section{4 .2 Operating Residuals}

Tables 2.5 and 2.6 summarize expected residuals from the corn stover and wheat straw systems, respectively. Both systems have considerable tonnages of solid waste. The corn stover (acid hydrolysis) system produces gypsum, a stable form of calcium sulfate. The enzymatic, wheat straw operation results in solid waste consisting of unhydrolyzed wheat solids with occluded enzyme cells. This study has not identified any problems associated with disposal of these solid wastes, and, in fact, crop soils may benefit from the constituent nutrients. Care must be taken, however, to ensure proper reuse of these materials, since leachates entering bodies of water would contain oxygen-consuming bacteria. 
Table 2.5. Estimated Emissions for $\mathrm{C}_{6}$ Sugar Production by the Tsao Process and for Ethanol Productiona

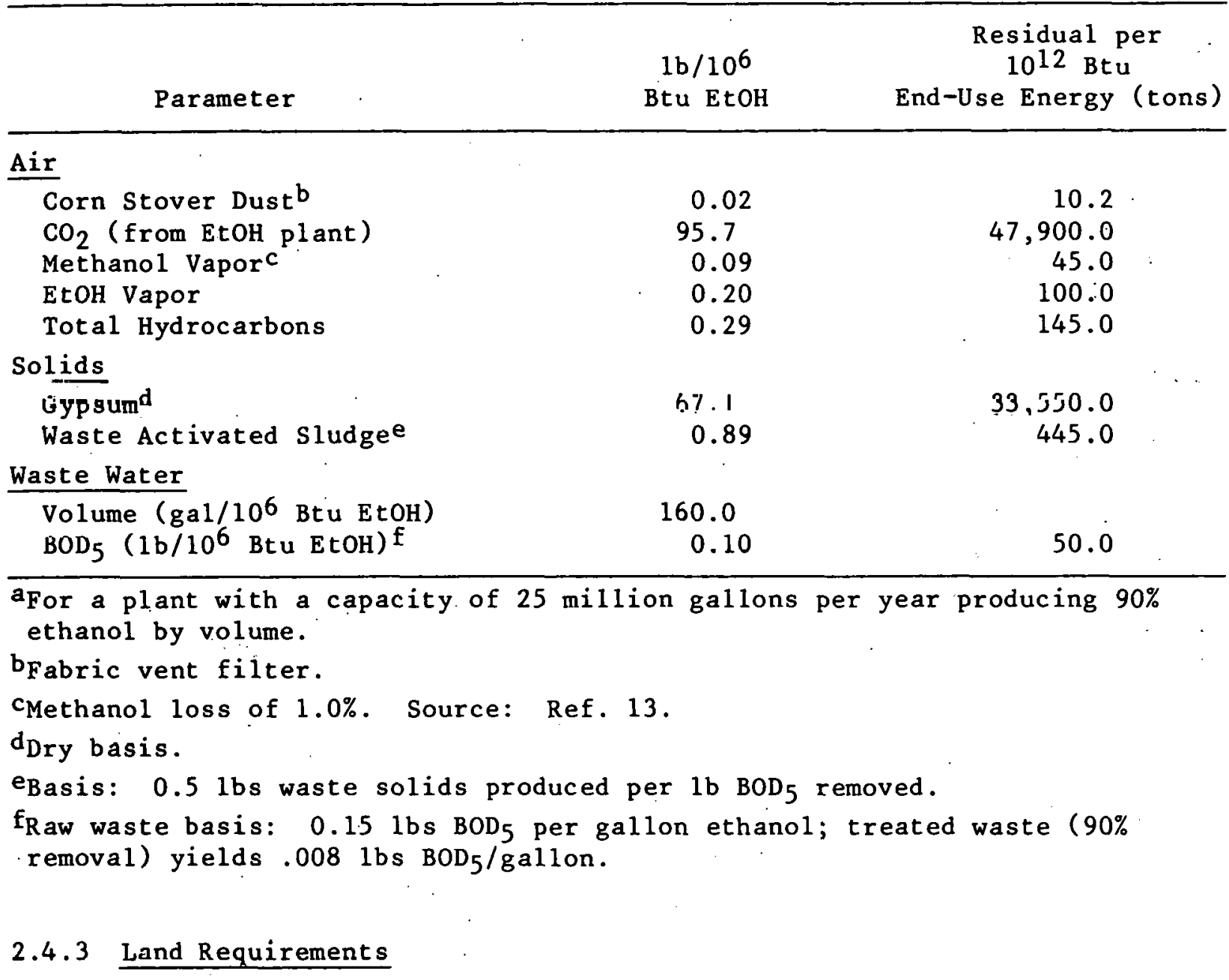

Approximately 120 acres of 1 and are required for the acid/hydrolysis ethanol plant combination. A site of 140 acres is required for the enzymatic hydrolysis/ethanol plant combination. These land requirements correspond to 60 acres and 70 acres per $10^{12}$ Btu of end-use energy per year for the acid system and enzymatic system, respectively.

\subsubsection{Water Requirements}

The two-stage, acid hydrolysis facility will require $1,800 \mathrm{gpm}$ of fresh water for the model selected. The corresponding. 25 million gallon ethanol plant requires about $700 \mathrm{gpm}$. The $2500 \mathrm{gpm}$ total corresponds to 47 gallons of water per gallon of 190-proof ethanol produced, or $5.9 \times 10^{8}$ gallons per 1012 Btu of end-usc cnergy.

Enzymatic hydrolysis of wheat straw requires $8,500 \mathrm{gpm}$ of cooling water and $3,700 \mathrm{gpm}$ of process water. 12 The adjacent $25 \mathrm{million}$ gallon ethanol plant will require about $800 \mathrm{gpm}$ of water, for a total of 13,000 gpm. This amounts to 247 galions of water per gallon of EtoH produced or $31 \mathrm{x}$ $10^{8}$ gallons of water per $10^{12} \mathrm{Btu}$ of end-use energy. 
Table 2.6. Estimated Emissions for $C_{6}$ Sugar Production by Enzymatic Hydrolysis of Wheat Straw

\begin{tabular}{|c|c|c|}
\hline Parameter & $\begin{array}{c}1 \mathrm{~b} / 10^{6} \\
\text { Btu EtOH }\end{array}$ & $\begin{array}{c}\text { Residual per } \\
10^{12} \text { Btu } \\
\text { End-Use Energy (tons) }\end{array}$ \\
\hline \multicolumn{3}{|l|}{$\underline{\text { Air }}$} \\
\hline $\begin{array}{l}\text { Wheat Milling and Handling } \\
\text { Carbon Dioxide (EtOH Plant) } \\
\text { Hydrocarbons (EtOH) }\end{array}$ & $\begin{array}{l}0.02 \\
95.7 \\
0.20\end{array}$ & $\begin{array}{r}10.0 \\
47,900.0 \\
100.0\end{array}$ \\
\hline \multicolumn{3}{|l|}{ Solids } \\
\hline $\begin{array}{l}\text { Waste Activated Solidsb } \\
\text { Enzyme Waste Cells } \\
\text { Unhydrolyzed Wheat Solids }\end{array}$ & $\begin{array}{r}0.89 \\
23.8 \\
552.0\end{array}$ & $\begin{array}{r}445.0 \\
11,900.0 \\
276,000.0\end{array}$ \\
\hline \multicolumn{3}{|l|}{ Waste Water (EtOH P1ant) } \\
\hline $\begin{array}{l}\text { Volume }\left(\mathrm{gal} / 10^{6} \text { Btu EtOH }\right) \\
\text { BOD }_{5}\left(1 \mathrm{~b} / 10^{6} \text { Btu EtOH }\right) \mathrm{C}\end{array}$ & $\begin{array}{r}160.0 \\
0.10\end{array}$ & 50.0 \\
\hline
\end{tabular}

a For a plant with a capacity of 25 million gallons per year producing $90 \%$ ethanol by volume.

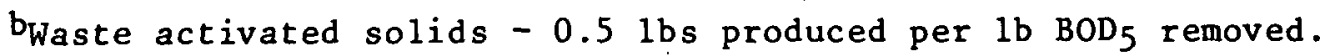

$C_{\text {Raw waste basis: }} 0.15$ Ibs BOD $_{5}$ per gallon ethanol; treated waste ( $95 \%$ remova1) yields 0.008 lbs $\mathrm{BOD}_{5} / \mathrm{gallon}$ ethanol.

\subsection{ECONOMIC DATA}

\subsubsection{Capital Costs}

Facilities costs for the acid and enzymatic hydrolysis plants are summarized in Tables 2.7 and 2.8 , respectively. The costs for the enzymatic system are much greater than those for the acid hydrolysis system (over $80 \%$ higher). Digestion times for the enzymatic hydrolysis are much longer than those for acid hydrolysis, and enzyme production and recovery are considerably more complex than acid and methanol recovery. Studies are continuing in these areas to find a more suitable and economically recoverable enzyme.

\subsubsection{Operating and Maintenance Costs}

Operational expenditures required for the two hydrolyzing methods (coupled with ethanol plants) are shown in Tables 2.9 and 2.10 . The overriding factor causing the higher operating costs for enzymatic hydrolysis is the materials cost for enzyme production -- about $7 \notin$ per pound of sugar produced ( 1972 base). SRI13 suggests that Corn Steep Liquor at a material cost of only $5 \notin / 1 b$ may eventually be substituted for Peptone ( $\$ 3$ per 1b). However, SRI also points out that more complete recovery of enzymes will be necessary before the system can begin to be attractive. 
Table 2:7: : Estimated Cost of :Plant Facilities for Production of

$\mathrm{C}_{6}$ Sugar from Cotn Stover by the Tsao Process. ${ }^{a}$

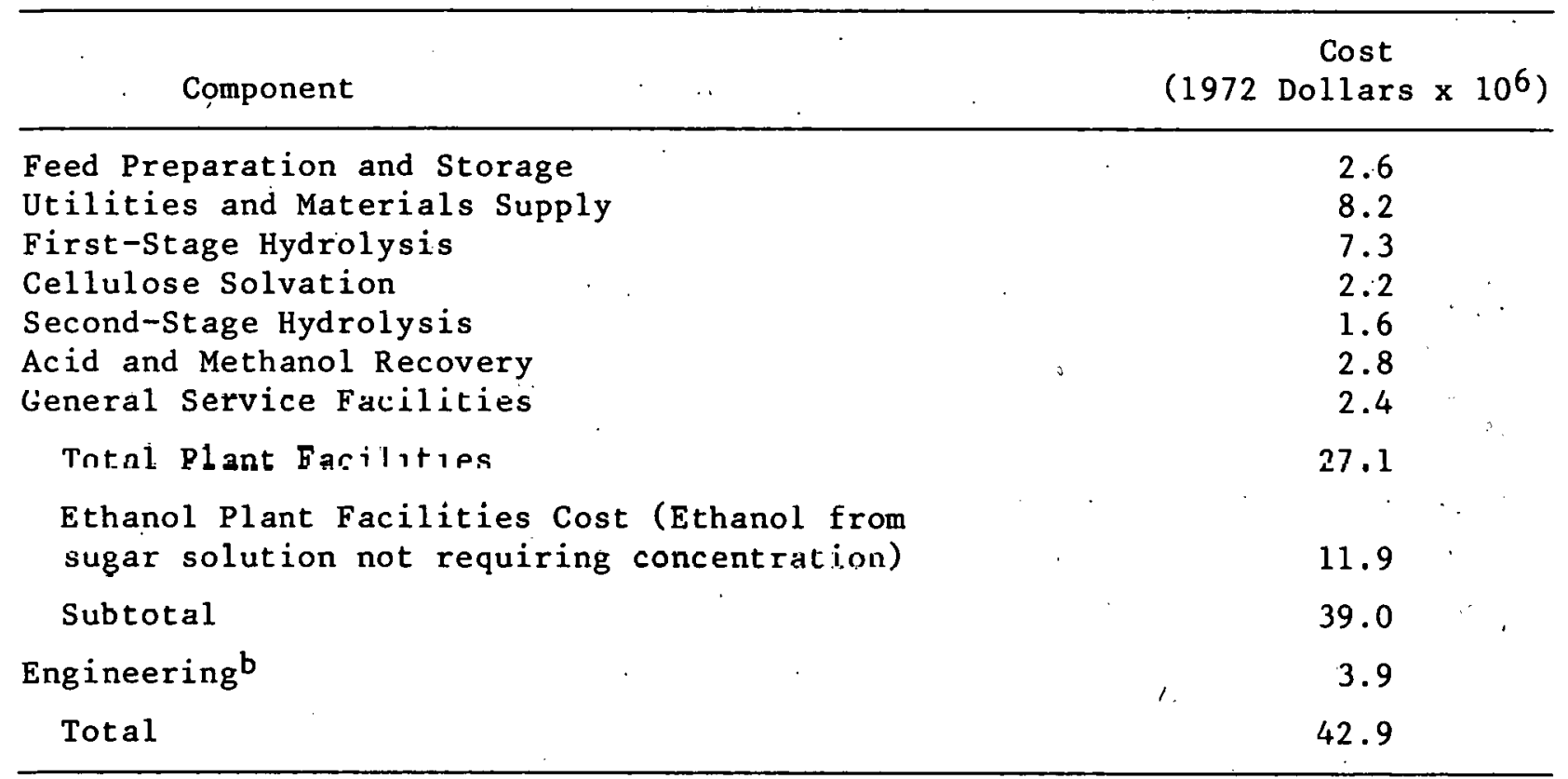

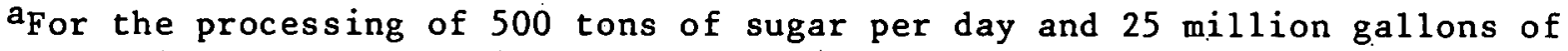
ethanol per year. 1978 dollars were deflated to 1972 dollars by a factor. of 1.48 .

bIncludes procurement, engineering details, and construction management.

Table 2.8. Estimated Cost of Plant Facilities for Production of $\mathrm{C}_{6}$ Sugar by Enzymatic Hydrolysis of Wheat Strawa

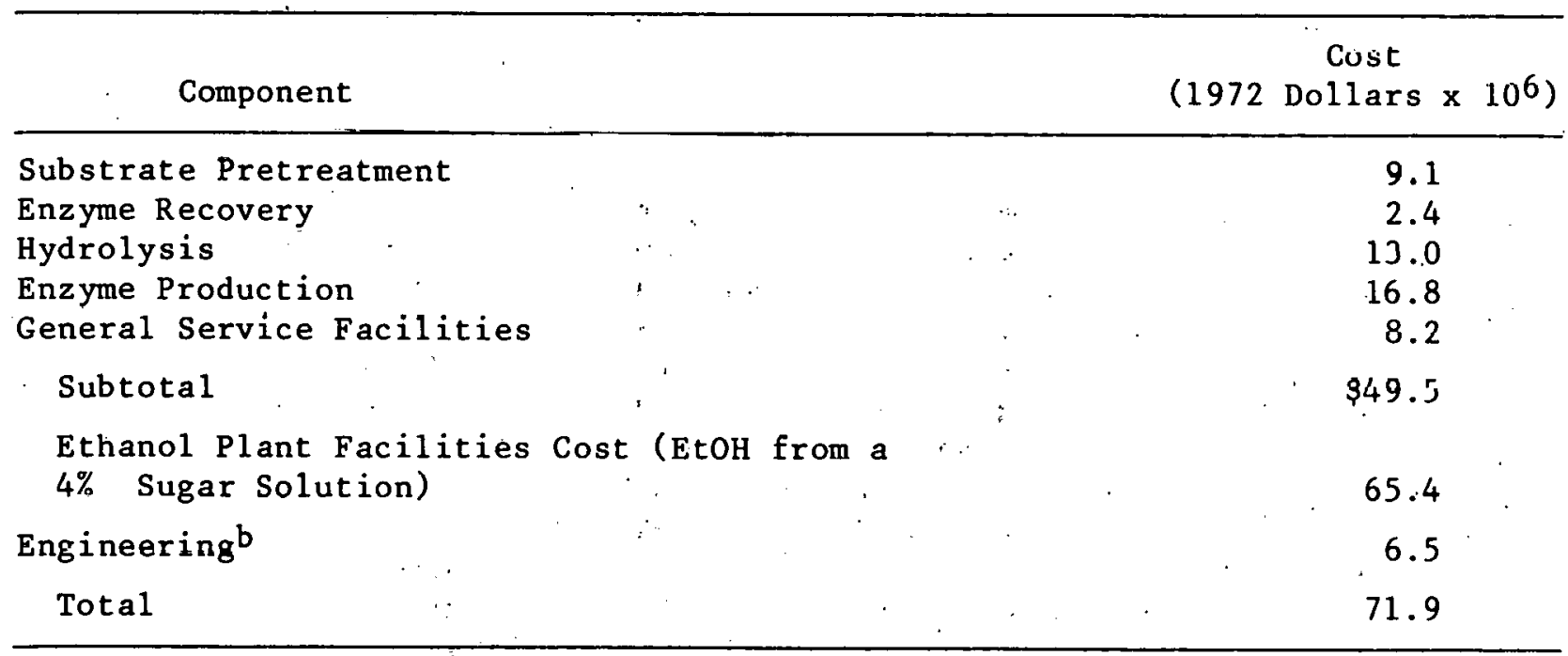

aproduction of sugar for an ethanol plant with a capacity of 25 million gallons per year. 1978 dollars were deflated to 1972 dollars by a factor of 1.48 .

bIncludes procurement, engineering details, and construction management. 
Table 2.9. Estimated Operating Costs for Tsao Hydrolysis Process and Combined Ethanol Planta

\begin{tabular}{|c|c|c|c|}
\hline Component & 1972 & 2 Dollars $\times 10^{6} /$ Year & $\begin{array}{l}\text { Dollars per } \\
\text { Gallon Ethanol }\end{array}$ \\
\hline Hydrolysis Plant & 2 & & \\
\hline $\begin{array}{l}\text { Lime } \\
\text { Sulfuric Acid } \\
\text { Methanol } \\
\text { Maintenance Materials } \\
\text { Labor } \\
\text { Utilities } \\
\text { G and A } \\
\text { Property Taxes \& Insurance } \\
\text { Plant Depreciation ( } 20 \text { years) }\end{array}$ & & $\begin{array}{l}0.82 \\
1.59 \\
1.14 \\
0.54 \\
1.58 \\
1.70 \\
0.54 \\
0.68 \\
1.64\end{array}$ & . \\
\hline $\begin{array}{l}\text { Cost Without Raw Material } \\
\text { Cost of Corn Stover }\end{array}$ & & $\begin{array}{r}10.23 \\
8.71\end{array}$ & $\begin{array}{l}0.41 \\
0.35\end{array}$ \\
\hline $\begin{array}{l}\text { Total - Hydrolysis } \\
\text { Ethanol Plant }\end{array}$ & & 18.94 & 0.76 \\
\hline $\begin{array}{l}\text { Chemicals } \\
\text { Maintenance Materials } \\
\text { Labor } \\
\text { Utilities } \\
\text { G and A } \\
\text { Property Tax and Insurance } \\
\text { Plant Depreciation ( } 20 \text { years) } \\
\text { Total Ethanol Plant }\end{array}$ & & $\begin{array}{l}0.01 \\
0.29 \\
1.26 \\
1.85 \\
0.29 \\
0.36 \\
0.88 \\
4.94\end{array}$ & 0.20 \\
\hline
\end{tabular}

${ }^{a_{F}}$ For ethanol plant with a capacity of 25 million gallons per year. 1978 dollars were deflated to 1972 dollars by a factor of 1.48 .

\subsection{SUMMARY OF FINDINGS}

Two processes for manufacturing ethyl alcohol from agricultural residues have been evaluated in this section." The processes differ in the hydrolysis method, that is, the conversion of cellulose to a fermentable sugar. One process involves a two-step acid treatment, whereas the other consists of hydrolysis catalyzed by an enzyme. Both methods are still experimental, but, of the two methods, the acid system appears the more promising because of considerably lower operating costs. This is largely due to the high projected cost of enzyme. Less costly enzymes could alter this picture. If ethanol is to be fermented on a scale large enough to make an impact as a fuel or fuel supplement for the transportation industry, it is imperative that available agricultural residues be utilized because of the very low cost of feedstock compared with that of the alternative -- grain. Environmental problems associated with these processes should be minimal. 
Table 2.10. Estimated Operating Costs for Enzymatic Hydrolysis of Wheat Strawa

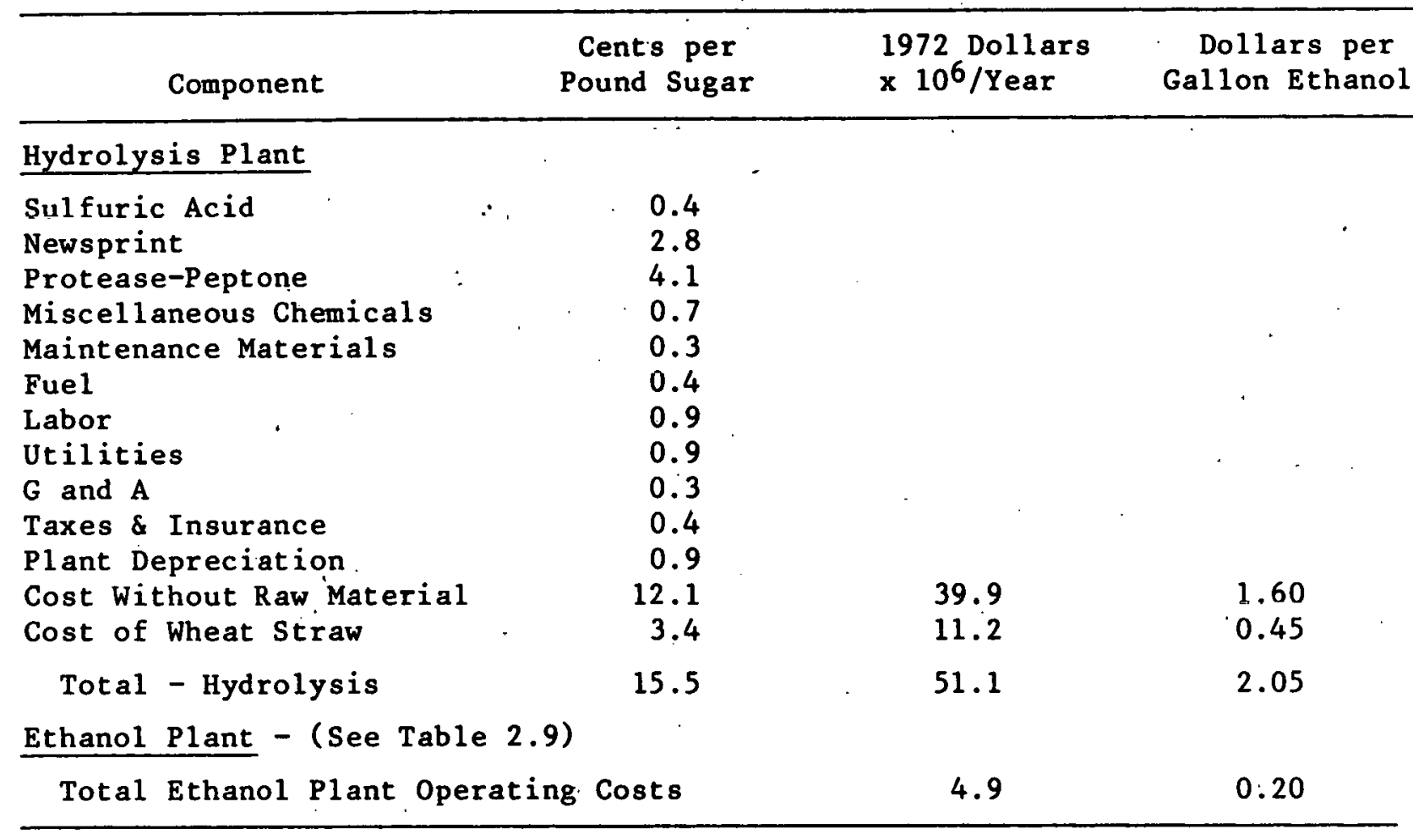

aproduction of 500 tons per day of $C_{6}$ sugar for an ethanol plant with a capacity of 25 million gallons per year. 1978 dollars were deflated to 1972 dollars by a factor of 1.48 .

Use of corn stover, or similar cellulosic material, will require the development of the infrastructure for harvesting, collection; and year-round storage. Collection techniques could be similar to those used in harvesting cane sugar in Louisiana and Florida, with the exception that compaction equipment will be necessary to reduce the large volume of the cellulosic material.

Because the high bulk of this material will result in low-weight payloads and thus increased transportation costs, careful study will have to be given to plant location. The development and use of special balers could reduce bulk, and improve this aspect of transportation.

It is doubtful whether more than two-thirds of the existing corn acreage can be economically served with the systems described here. Although reasonably" low costs in raw material transportation can be anticipated in Indiana, Illinois, and Iowa, the more dispersed acreage of the other half of U.S. corn production will be difficult to serve. A traffic study will be required to help solve the problem of site selection. . 
3 ALCOHOLS FROM WOOD

\subsection{INTRODUCTION}

\subsubsection{General Description}

Two methodologies for the production of alcohol from wood will be described in this section. These are the processes for manufacture of methanol $\left(\mathrm{CH}_{3} \mathrm{OH}\right)$ and ethanol $\left(\mathrm{C}_{2} \mathrm{H}_{5} \mathrm{OH}\right)$. Although the two alcohols are of the same general aliphatic family, the production processes are different. Methanol production is based on the gasification of wood to produce a medium-Btu fuel gas (mainly $\mathrm{CO}$ and $\mathrm{H}_{2} \mathrm{O}$ ) followed by a shift reaction to oxidize part of the $\mathrm{CO}$ to form $\mathrm{H}_{2}$ as follows:

$$
\mathrm{H}_{2} \mathrm{O}+\mathrm{CO} \neq \mathrm{H}_{2}+\mathrm{CO}_{2}
$$

$\mathrm{CO}$ is then combined catalytically with $\mathrm{H}_{2}$ to produce methanol, $\mathrm{CH}_{3} \mathrm{OH}$. Ethanol is derived from wood by a two-step process consisting of hydrolysis of wood to sugars followed by fermentation of the sugars to alcohol.

\subsubsection{Resource Distribution}

Forestry residues that can be used as biomass for alcohol manufacture are principally "slash" -- cuttings left behind after conventional logging -and stump/root systems. Total logging residues in the Unites States approach 200 million tons per year divided about $40 / 60$ between above ground residues and stump/root systems.16 The availability of these residues varies depending on forest type, topography, soil strength, erosion potential and other factors. Collection and use of these residues will be dependent on development of harvesting equipment, some of which has already been developed by companies such as Morbark Industries.16 Chipping machines located on logging sites may enhance the collection of residues.

Lumber mills and pulp/paper mills are also sources of large amounts of wood residues -- approximately half of the timber processed into lumber and plywood is wasted in the form of bark, sawdust and trim at the wood mill site. Bark is also unusable for pulp production although it is often burned as a source of steam for the process. Black liquors associated with the Kraft process of pulp making contain residual soluble organics and cellulosic fibers unusable in paper making. The liquor is concentrated and reused to recover chemicals required in the pump cooking process. However, recoverable cellulose contained in pulping waste can be converted to sugar by hydrolysis. Georgia Pacific recently made its first shipment of 200-proof alcohol make from pump and paper mill by-products. A recent assessment has estimated that forest industry wastes ( 1 umber and pulp mills included) total about 23 million tons per year.18. Thus, the largest potential, by far, for biomass fuels is from forest. residues ( 200 million tons) rather than from industrial wastes. However, if forestry residue collection becomes economical, alternative uses will compete with bioconvergion. 
Silverculture (cultivation of trees) for the purpose of producing biomass for fuel has been intensely studied. Rapidly growing trees planted in close proximity and harvested in whort rotation as spindly trees can be expected to yield more biomass than does conventional long rotation forestry.16 However, private investment in silvicultural biomass farming will depend on how biomass fuel economics compare with those to competitive uses of wood (fiber and pump industries).

Model plant descriptions for ethanol and methanol facilities will assume a feedstock supply equivalent to 1000 tons (oven dry) of wood per day. If this feedstock were to be derived entirely from silviculture, an energy farm of roughly 40,000 acres. would be required assuming a yield of 10 oven dry tons per acre per year.16 Large silviculture energy farms do exist, although not in the U.S.; relatively large $(20,000$ acres) eucalyptus farms that supply charcoal for the steel industry have operated in South America for the past 25 years. Eucalyptus plantations providing fecdstock for fuels and chemicals also exist in Australia.

\subsection{MODEL SYSTEM - METHANOL FROM WOOD}

\subsubsection{Description}

Figure 3.1 is a schematic of the process described in this report.18 The facility uses a feedstock of 1,000 dry tons per day, and production of 56 million gallons of methanol per year may be expected.

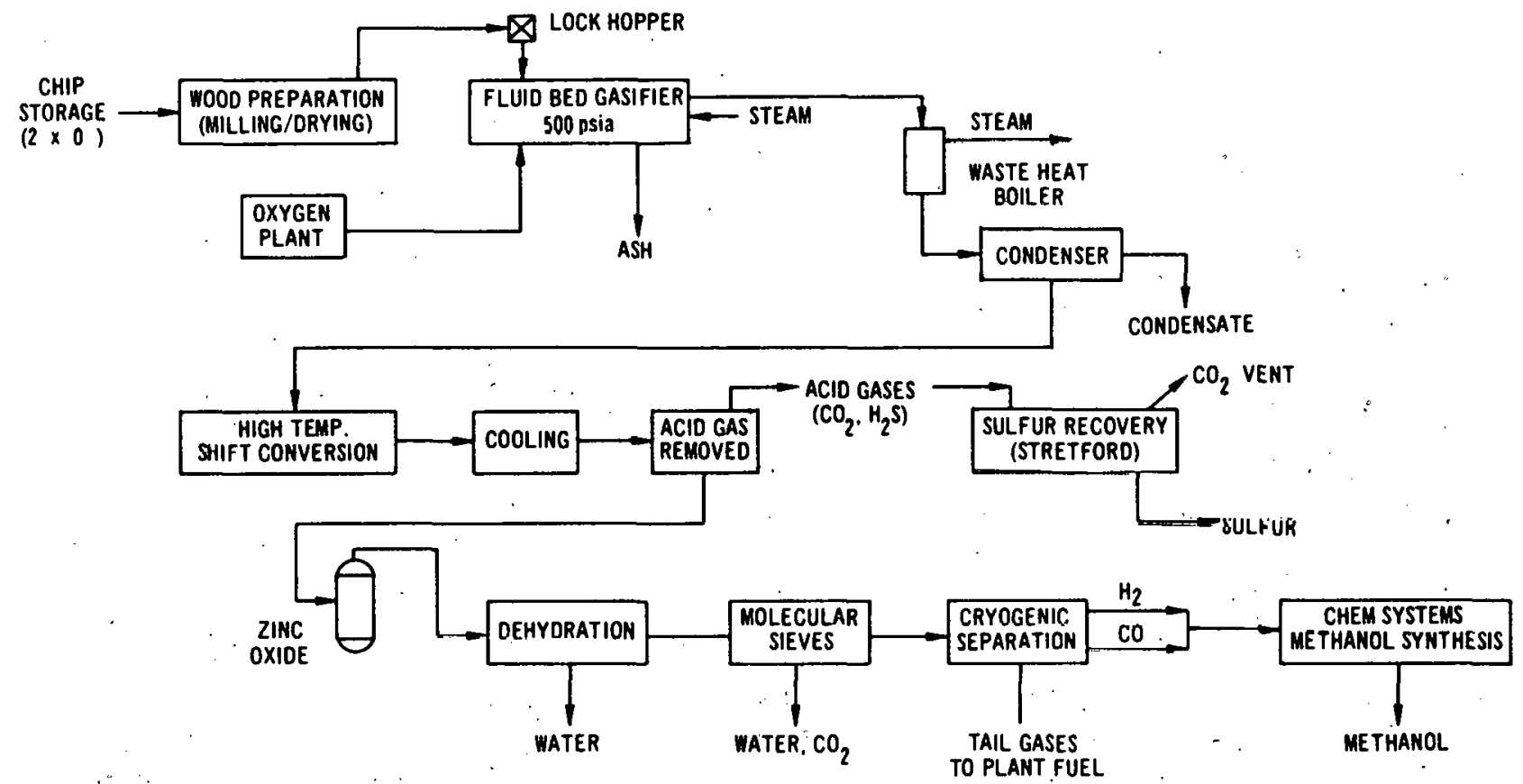

Fig. 3.1. Derivation of Methanol from Wood

(Source: Ref. 17) 
The wood is taken from chip storage and prepared for :gasification by drying and redicing the chips (2-inch chips are assumed available) to a size of $3 / 8$ inch using rotary driers, hammer mills, and shredders. Complete drying is not warranted because some moisture will be needed to produce the steam required for shift conversion. In addition, the thermal requirements for complete drying wouldibe severe.

Chips are fed through a lock-hopper system to a fluid-bed gasifier operating at $500 \mathrm{psi}$. Oxygen is fed to the gasifier from an $\mathrm{O}_{2}$ plant providing $98 \%$ oxygen at $520 \mathrm{psi}$. Ash and unconverted carbon exit from the gasifier base to be quenched and sent to disposal. Product gases ( $\mathrm{CO}$ and $\mathrm{H}_{2}$ primarily) are cooled in a waste heat boiler condensing sufficient water to permit the shift reaction to occur in the gas phase as follows:

$$
\mathrm{CO}+\mathrm{H}_{2} \mathrm{O}=\mathrm{H}_{2}+\mathrm{CO}_{2}
$$

A molar ratio of 1.8 to $1\left(\mathrm{H}_{2}: \mathrm{CO}\right)$ is selected on the basis of the need of approximately a 2:1 ratio for methanol synthesis. After shifting, gases flow to an acid gas removal system where $\mathrm{H}_{2} \mathrm{~S}$ and $\mathrm{CO}_{2}$ are separated. The $\mathrm{H}_{2} \mathrm{~S}$ in the acid gases may be removed by conventional sulfur recovery (Stretford). Final removal of sulfur compounds should be accomplished by passing through zinc oxide beds. Near total sulfur removal is necessary to avoid poisoning the sulfur-sensitive, shift-conversion catalysts.

The sulfur-free gas is then dehydrated by absorption chilling, which removes most of the moisture. Molecular sieves remove the last traces of water and $\mathrm{CO}_{2}$ prior to the cold box (eryogenic separation): In this step, three streams are separated, an $\mathrm{H}_{2}-\mathrm{rich}$ stream, a CO-rich stream, and a "tails" stream. Hydrogen and carbon monoxide streams are combined at a $2: 1$ molar ratio and fed to methanol synthesis. The tails are reused as plant fuel.

The process of methanol synthesis $\left(2 \mathrm{H}_{2}+\mathrm{CO}=\mathrm{CH}_{3} \mathrm{OH}\right)$ under development by Chem Systems 17 takes place in a fluidized catalyst bed. Gaseous effluents are cooled to condense the methanol product.

\subsubsection{Energy and Material Flows}

Table 3.1 indicates the material and energy flows for the production of methanol from wood. Note that only $2,200 \mathrm{~kW}$ of power is required to operate this plant over and above the recoverable energy supplied by the feedstock. Nearly all of the process energy required is recouped by the gasifier waste heat boiler, heat recovery from shift effluent, and tailing gases from the cryogenic gas separation. Energy from outside fuel is only $5 \%$ of the net energy produced in the form of methanol. Overall energy efficiency [output of the product methanol divided by-input (wood plus electricity)] is $62.5 \%$. 
Table 3.1. Material and Energy Flows for Production of Methanol from Wooda

\begin{tabular}{|c|c|c|}
\hline System Variable & Material & $\begin{array}{c}\text { Enérgy } \\
\left(10^{9} \mathrm{Btu} / \mathrm{day}\right)\end{array}$ \\
\hline $\begin{array}{l}\text { Wet Wood ( } 50 \% \text { moist) } \\
\text { Oxygen } \\
\text { Water } \\
\text { Methanol ( } 95 \%) \\
\text { Ash \& Uncoverted Carbon } \\
\mathrm{CO}_{2} \text { to Stack } \\
\text { Electricity } \\
\text { Fuel (to produce } 2,2 \cup \cup \mathrm{kW} \text { ) }\end{array}$ & $\begin{array}{l}2,000 \text { tons } / \text { day } \\
504 \text { tons } / \text { day } \\
1,548 \mathrm{gpm} \\
56 \mathrm{million} \text { gal } / \mathrm{yr} \\
\text { or } 170,000 \mathrm{gal} / \mathrm{day} \\
25.2 \mathrm{tons} / \mathrm{day} \\
1,000 \mathrm{tons} / \mathrm{day} \\
2,200 \mathrm{~kW} \\
1.1 \mathrm{ton} / \mathrm{hr}\end{array}$ & $17^{b}$ \\
\hline
\end{tabular}

a For the processing of 1,000 dry tons of wood per day, 330 days per year.

bSource: Ref. 14 .

$c_{\text {Based on }} 30 \%$ conversion efficiency of coal to electricity.

\subsection{MODEL SYSTEM - ETHANOL - FROM WOOD}

\subsubsection{Description . . 3iv}

The process for deriving ethyl alcohol from wood is based on hydrolysis of the cellulose in wood to sugar, which is then fermented to alcohol. Cellulosic fiber may be hydrolyzed either by acid treatment or enzymatically as described previously for corn and wheat residues. The most advanced process for wood described by MITRE 14 . is based on the Scholler process, which utilizes dilute sulfuric acid. The U.S. Forest Products Laboratory 18 has experimented with the process and has developed the flow diagram shown in Figure 3.2. In this case, the selected model will process 1,000 oven dry tons of feedstock per day and will produce 100,000 gallons per day of 190-proof ethyl alcohol.

Wood chips are digested with sulfuric acid and steam at $300^{\circ} \mathrm{F}$ for 15 minutes together with a recycled prehydrolysate stream. This hydrolysate is drained, and dilute $\mathrm{H}_{2} \mathrm{SO}_{4}$, is added together with high pressure steam for the main hydrolysis, requiring 70 minutes digestion. Digester contents are relused to the atmosphere with subsequent separation of furfural, lignins, and methanol in a distillation column. Hot hydrolysate is neultalized with lime, and precipitated gypsum is separated in a clarifier. The gypsum is filtered and washed and the filtrates flow to the fermenters together with clarifier overflow. $C_{6}$ sugar is converted to alcohol by conventional fermentation. The alcohol distillation system consists of a stripping column, extractive tower (aldehyde removal) and rectifying column (ethanol concentration), and produces 190-proof ethyl alcohol. The rectifying tower bottoms may be concentrated by multiple effect evaporators to produce concentrated pentose sugars. These $C_{5}$. sugars are available for possible conversion to butanediol or to ethanol. 


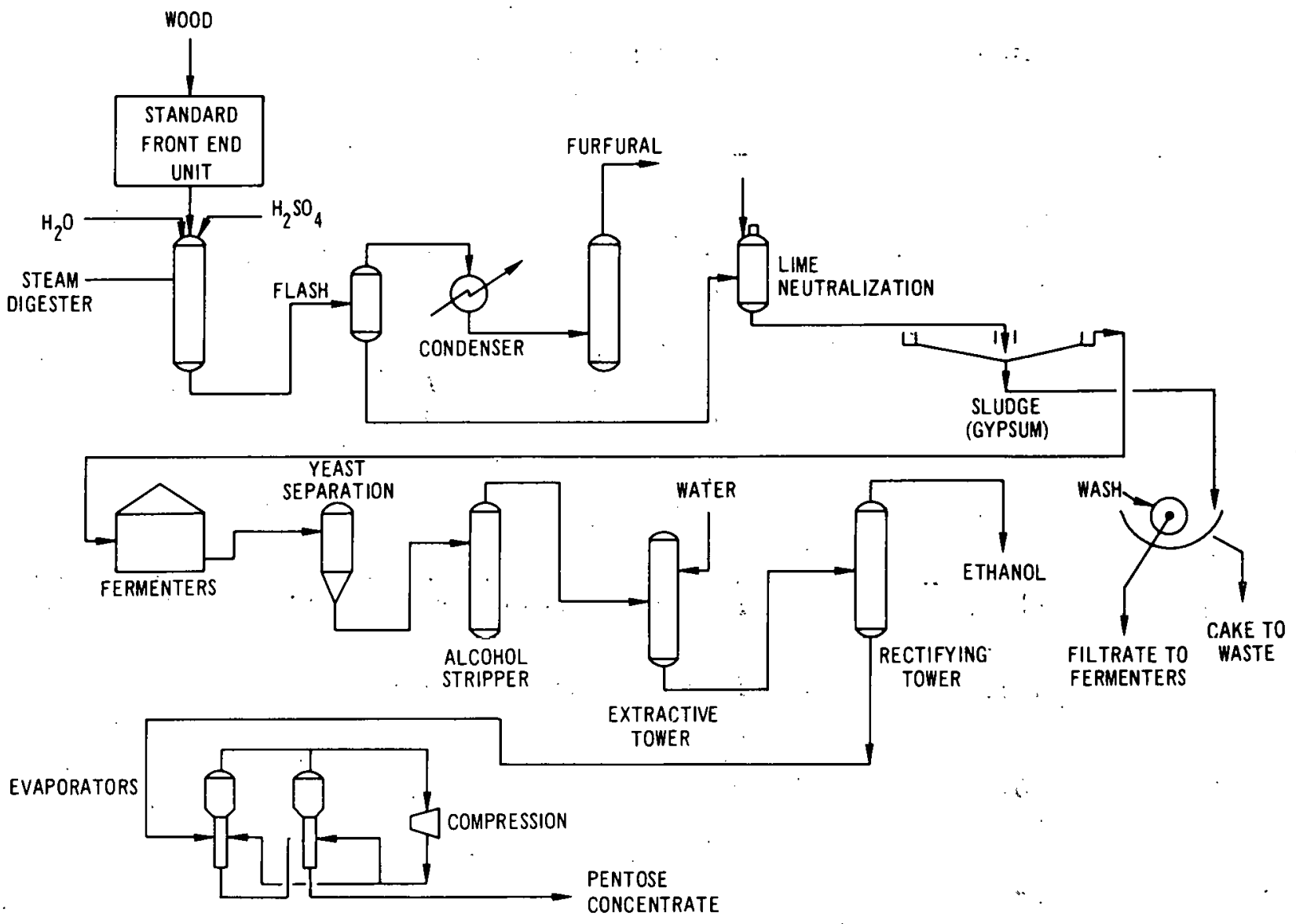

Fig. 3.2. Derivation of Ethanol from Wood

\subsubsection{Energy and Material Flows - Ethanol}

Material and energy values for the model described here are summarized in Table 3.2. Required fuel input has been calculated to be approximately 18 tph of coal for the model size plant. Part of the process steam requirements can be produced by burning lignin separated within the process. Lignin content in green wood is assumed to be about $8.5 \% .12$ Further, the heating value of 1 ignin is assumed to be $5,300 \mathrm{Btu} / 1 \mathrm{~b}$ of green wood.12 The total heat available from 2000 tpd of green wood ( 1000 oven dry tpd) would be only $1.8 \times 10^{9}$ Btu per day. The study assumed a total nominal heat requirement of 100,000 Btu per gallon of ethanol produced (see the section on corn-toalcohol) or $10.0 \times 10^{9} \mathrm{Btu} / \mathrm{day}$ for the $100,000 \mathrm{gal} / \mathrm{day}$ facility. The requirement for outside purchased fuel (coal) would be about $18 \mathrm{tph}$ to make up the shortage of $8 . \dot{2} \times \cdot 1 \dot{U}^{9}$ Btu/day.

\subsection{ENVIRONMENTAL DATA}

\subsubsection{Environmental Consequences of Wood-Utilization}

Forest "slash" (cuttings lcft" behind logging operations) will not degrade the environment if properly harvested. Silviculture energy farms 
Table 3.2. Material and Energy Flows for. Production of Ethanol from Wooda

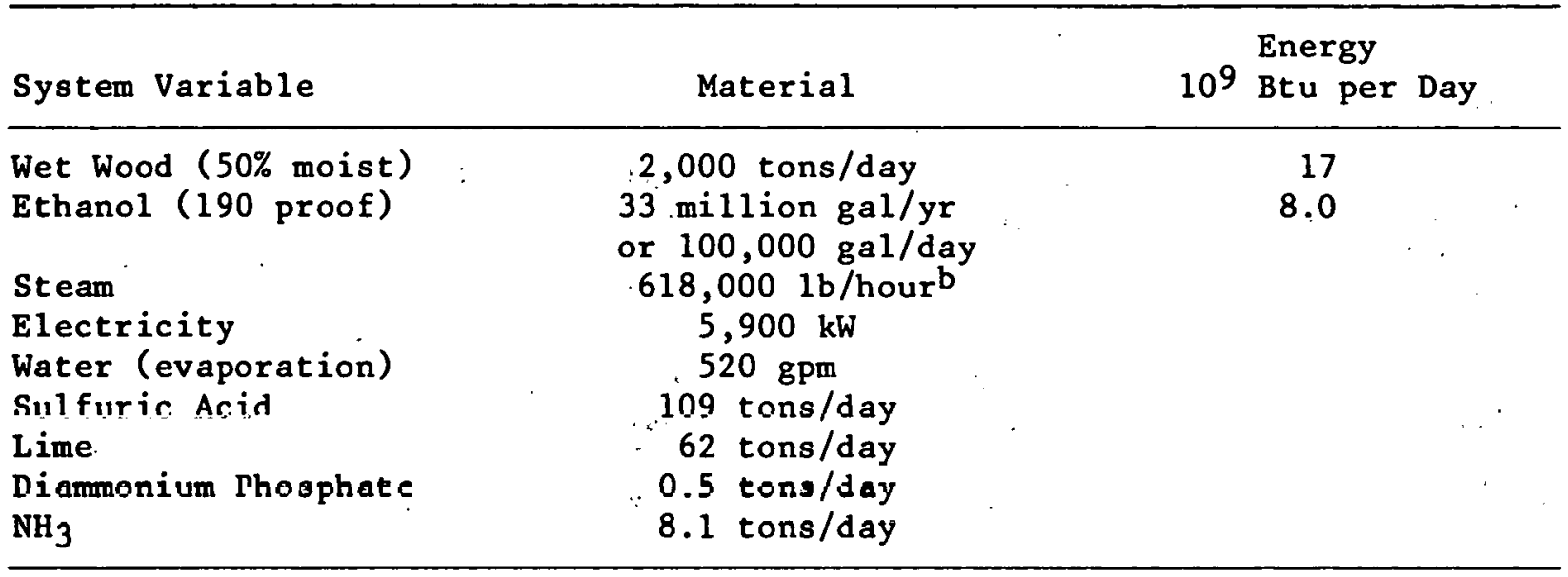

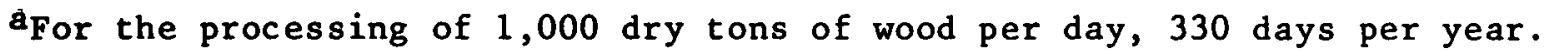

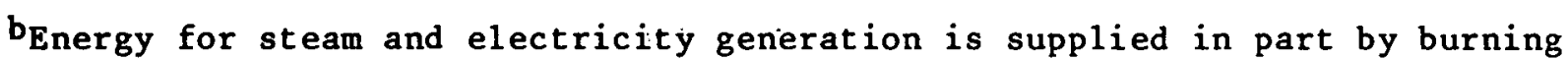
of lignins derived from the wood feedstock. Assuming 100,000 Btu total fuel required per gallon of product, approximately $18 \mathrm{tph}$ coal is required over and above the heating value of the lignin. Since there are much better uses for lignin than burning, it may be more economical to recover it as a byproduct and derive all of the energy from coal.

with intensive cultivation practices may, however, result in severe problems unless properly implemented.16. The effects of short-rotation tree farming on soil productivity and erosion are not well-known. If new lands are cultivated, natural ecosystems of 1 arge acreages will be altered.

Silviculure should not contribute to air pollution such as that which results from dusting in agricultural farming. However, sediment loading of waterways will result from conventional logging techniques. Large-scale cultivation of trees for energy production would reduce land availability for fiber production. However, once even marginal land has been demonstrated as productive, competition from the fiber market would be initiated. Solid wastes from biomass farms should be minimal since optimum use of the yield should be the prime goal of biomass technology.

\subsubsection{Land Requirements}

We estimate a land requirement of 60 acres per $10^{12} \mathrm{Btu}$ of end-use energy per year for both the methanol and ethanol facilities. For the model plants suggested, acreage requirements will be 218 acres and 159 acres for the methanol and ethanol facilities, respectively.

\subsubsection{Water Requirements}

Approximately 200 gallons of fresh water per $10^{6}$ Btu of end-use energy is required for the methanol, or $1,530 \mathrm{gpm}$ for the model described. This 
corresponds to $2 \times 10^{8}$ gallons per $10^{12} \mathrm{Btu}$. For the production of ethanol from wood, 93.5 gallons are required per $10^{6} \mathrm{Btu}\left(0.0 \times 10^{8} \mathrm{gal} / 10^{12} \mathrm{Btu}\right)$ or $519 \mathrm{gpm}$ for the model.

\subsubsection{Operating Residuals}

Estimated air emissions as well as solid and liquid wastes. associated with the gasification of wood and synthesis of methyl alcohol are suminarized in Table 3.3. Table 3.4 contains the same information for the ethanol process.

Air emissions from burning of coal to produce steam have not been taken into account. These values may be estimated, if desired, by assuming New Source Performance Standards (NSPS) for burning of coal (0.6 $1 \mathrm{bs} / 10^{6} \mathrm{Btu}$ of fuel for $\mathrm{SO}_{2}$ and $\mathrm{NO}_{\mathrm{x}} ; 0.03 .1 \mathrm{bs} / 10^{6} \mathrm{Btu}$ of fuel for flyash).

Table 3.3. Residuals from Production of Methanol from Wooda

\begin{tabular}{|c|c|c|c|c|}
\hline Residual & $\begin{array}{c}1 \mathrm{~b} / 10^{6} \\
\text { Btu MeOH }\end{array}$ & tons/day & $\begin{array}{c}\text { Residuals } \\
\text { per } 10^{12} \text { Btu } \\
\text { End-Use Energy }\end{array}$ & (tons) \\
\hline \multicolumn{5}{|l|}{ Air } \\
\hline $\begin{array}{l}\text { Particulates } b \\
\text { Hyd rocarbons } \\
\mathrm{CO}_{2}\end{array}$ & 0.08 & $\begin{array}{r}0.44 \\
1.40 \\
1,000\end{array}$ & $\begin{array}{l}40 \\
127.4 \\
91,000\end{array}$ & · \\
\hline \multicolumn{5}{|l|}{ Solids } \\
\hline $\begin{array}{l}\text { Ash \& Unburned Carbon } \\
\text { Waste Activated Solids }\end{array}$ & & $\begin{array}{r}25.2 \\
6.0\end{array}$ & $\begin{array}{l}2,293 \\
546\end{array}$ & \\
\hline Liquids & & & & \\
\hline $\begin{array}{l}\text { Waste After Treatment: } \\
\text { BOD }_{5} \text { d } \\
\text { Flow }(645 \mathrm{gpm}) 18\end{array}$ & & 0.64 & 58.2 & \\
\hline
\end{tabular}

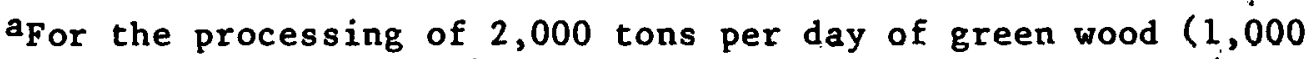
oven dry tons per day) and the production of $170,000 \mathrm{gal} / \mathrm{day}$ of methanol.

bFrom wood room.

CEstimated loss of $0.25 \%$ product to dir.

dBasis: Raw waste contains $0.15 \cdot 1 \mathrm{~b} \mathrm{BOD}_{5}$ per gal МeOH.

Activiated sludge treatment ( $95 \%$ removal) yields

$0.008 \mathrm{lb} \mathrm{BOD}_{5}$ per gal $\mathrm{MeOH}$.

Wasted solids $=0.5 \mathrm{lb}$ per $1 \mathrm{~b} \mathrm{BOD}_{5}$ removed. 
Table 3.4. Residuals from Production of Ethanol from Wooda

\begin{tabular}{|c|c|c|c|c|}
\hline Residual & $\begin{array}{c}1 \mathrm{~b} / 10^{6} \\
\text { Btu EtOH }\end{array}$ & tons/day & $\begin{array}{r}\text { Residuals pe } \\
\cdot 10^{12} \text { Btu } \\
\text { End-Use Energy }\end{array}$ & (tons) \\
\hline \multicolumn{5}{|l|}{ Air } \\
\hline $\begin{array}{l}\text { Particulates }{ }^{b} \\
\text { Hydrocarbons } \\
\text { Carbon Dioxide }\end{array}$ & $\begin{array}{l}0.11 \\
0.20 \\
95.7\end{array}$ & & $\begin{array}{c}55 \\
100 \\
47,850\end{array}$ & \\
\hline \multicolumn{5}{|l|}{ Solids } \\
\hline $\begin{array}{l}\text { Gypsum } \\
\text { Waste Activated Sol }\end{array}$ & $d_{s}^{d}$ & $\begin{array}{l}122 \\
3.6\end{array}$ & $\begin{array}{l}15,250 \\
450\end{array}$ & \\
\hline \multicolumn{5}{|l|}{ Lif quids } \\
\hline $\begin{array}{l}\text { Waste After Treatme } \\
\text { BOD5d } \\
\text { Flow }(1,250 \mathrm{gpm}) \mathrm{e}\end{array}$ & & 0.4 & 50 & \\
\hline
\end{tabular}

${ }^{a_{F}}$ For the processing of 2,000 tons per day of green wood $(1,000$ oven dry tons per day) and the production of 100,000 gallons of ethanol per day.

bFrom wood room only.

cThis estimate is based on a $10 s$ s of $0.25 \%$ of the product to the air.

dBasis: Raw waste contains $0.151 \mathrm{~b} \mathrm{BOD}_{5}$ per gal EtOH. (personal communication with personnel of Distillery Plant A).

Activiated sludge treatment ( $95 \%$ removal) yields .008 lbs BOD 5 per gal EtOH. Wasted solids $=0.5 \mathrm{lb}$ per $1 \mathrm{~b} \mathrm{BOD}_{5}$ removed.

eFlow is based on a raw waste strength of $1,000 \mathrm{mg} / 1 \mathrm{~b} \mathrm{BOD}_{5}$ (Elnw 18 gallons/gal EtOH).

Woodroom air, emissions from grindilly, sizing, and handling of chips have been estimated from the followiug equations utilizen by Wisconsin's Dept. of Natural Resources:*

1) $E=(3.59) \times(P) 0.62$ where $E=$ controlled dust emission in lbs/hour; $P=$ tons wood/hour This equation applies when $P$ is less than $30 \mathrm{tph}$.

2) When $P$ is greater than $30 \mathrm{tph}$, use: $E=(17.31) \times(P) 0.16$

*Personal communication. Department of Natural Resources, Madison, Wisconsin. 


\section{3:5 ECONOMIC DATA}

\subsubsection{Capital Costs}

Tables 3.5 and 3.6 summarize the estimates of facilities expenditures for the methanol and ethanol processes, respectively, in 1972 dollars. Total capital costs are $\$ 61.7$ million for methanol production and $\$ 82.7$ million for ethanol production. The estimating sources 14,19 for these two processes were not the same and there are bound to be some inconsistencies. However, we believe the relative plant costs are reasonably accurate.

\subsubsection{Operating and Maintenance Costs}

Annual operational costs are listed in Tables 3.7 and 3.8 for methanol and ethanol production, respectively. Note that costs are also listed per gallon of product (in 1972 dollars). The wide difference in costs between methanol production ( $28 \notin / g a l)$ and ethanol production ( $91 k / g a 1$ ) is partly due to the higher plant capital cost but is also due to the much higher yield of the gasification process. For the same feedstock tonnage ( 2000 tons green wood/day), 56 million gallons of methanol are produced, and only 33 million gallons of ethanol are produced.

\subsection{SUMMARY OF FINDINGS}

Higher yields of methanol ( $170,000 \mathrm{gal})$ than ethanol (100,000 gal) are obtained from the model plant processing 1,000 oven dry tons of wood.

Table 3.5. Capital Costs for Facilities Producing Methanol from Wood by Gasification and Chemical Synthesisa

\begin{tabular}{lc}
\hline \multicolumn{1}{c}{ Item } & $\begin{array}{c}\text { Cost } \\
\left.\text { (1972 Dollars } \times 10^{6}\right)\end{array}$ \\
\hline Wood Storage, Handling, and Preparation & 3.3 \\
Wood Gasification & 11.7 \\
Shift Conversion & 1.0 \\
Acid Gas Removal & 3.8 \\
Oxygen Plant & 8.0 \\
Cryogenic Separation & 2.9 \\
Syngas Compression & 0.9 \\
Methanol Synthesis & 5.4 \\
Sulfur Recovery & 1.3 \\
Uetility facilities & 15.3 \\
General Service Facilities & 8.1 \\
$\quad$ Total & 61.7 \\
\hline
\end{tabular}

a Feedstock $=1,000$ oven dry tons of wood per day. 1977. dollars ware deflated to 1972 dollars by a factor of 1.43 . 
Table 3.6. Capital Costs for Facilities Producing Ethanol by Acid Hydrolysis and Fermentationa

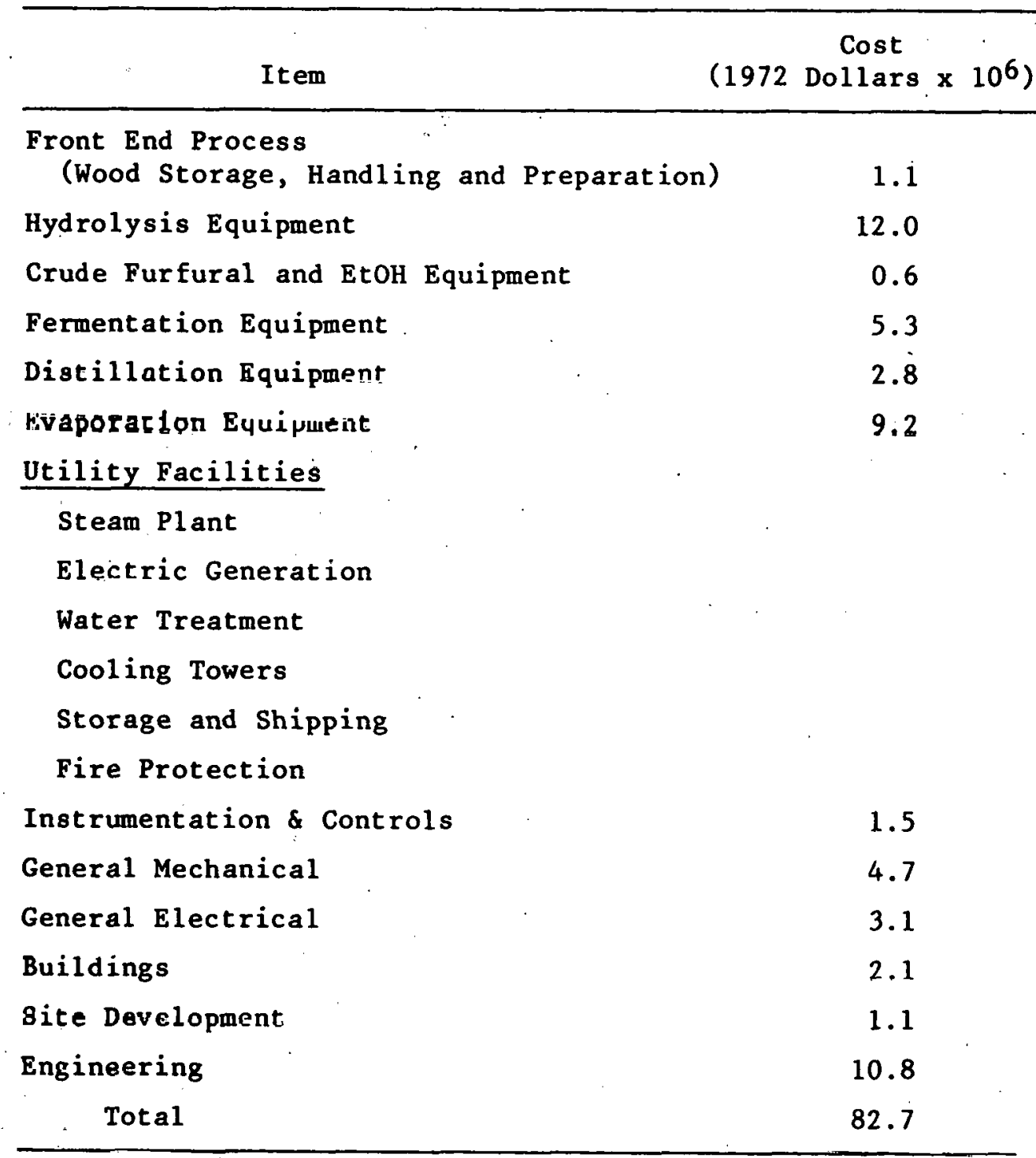

a Feedstock $=1,000$ oven dry tons of wood per day. 1977 dollars were deflated to 1972 dollars by a factor of 1.43 .

The higher methanol yleld somewhat uffsets the higher residuals per gallon of methyl alcohol caused by this gaoification process. Both processes are much more energy efficient than the other alcohol production processes discussed, because spent solids ( 1 ignin and/or fiber) are more readily available to be utilized as a fuel source to provide steam.

Liquid wastes will cuntain alcohols and should be completely biodegradable. Solid wastes will be relatively innocuous (ash in the case of methanol and gypsum for the ethanol process), and disposal should offer no problems. It remains to be seen, however, whether the use of wood biomass for alcohol production can compete in the private sector with the use of wood biomass for the production of pump and paper or fibrous products. 
Table 3.7. Operating and Maintenance Costs for the Production of Methanol from Wooda

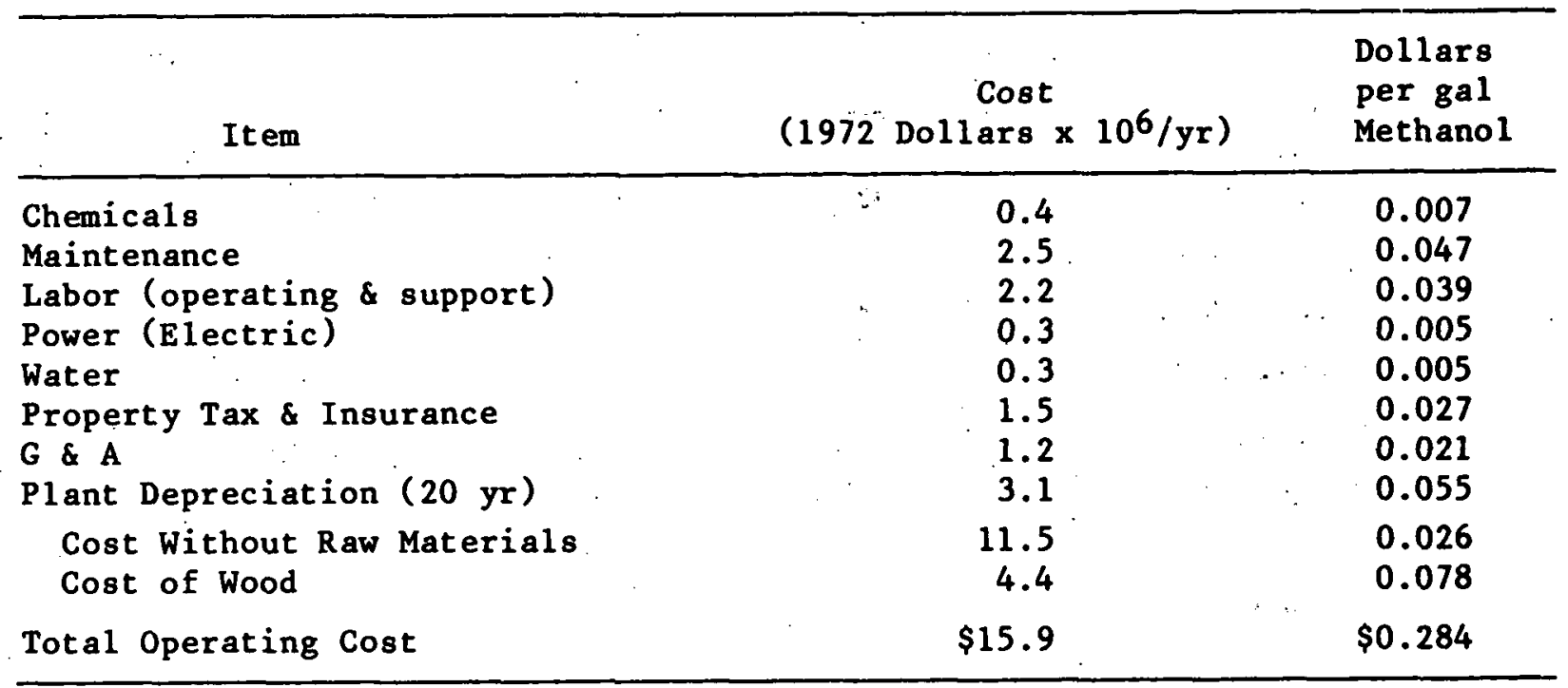

$\mathrm{a}_{\text {Feedstock }}=1,000$ oven dry tons of wood per day.

Table 3.8. Operating and Maintenance Costs for Production of Ethanol from Wooda

\begin{tabular}{|c|c|c|c|c|}
\hline It em & (1972 & $\begin{array}{r}\text { Cost } \\
\text { Dollars }\end{array}$ & x. $\left.10^{6} / \mathrm{yr}\right)$ & $\begin{array}{l}\text { Dollars } \\
\text { per gal } \\
\text { Ethanol }\end{array}$ \\
\hline $\begin{array}{l}\text { Chemicals }^{\mathrm{b}} \\
\text { Maintenance } \\
\text { T.abor } \\
\text { Power } \\
\text { Other Utility } \\
\text { G \& A } \\
\text { Property Tax \& Insurance. } \\
\text { Plant Depreciation (20 yr) }\end{array}$ & . & $\begin{array}{c}2.0 \\
6.3 \\
10.3 \\
0 \\
0.1 \\
1.3 \\
1.7 \\
4.1\end{array}$ & . & $\begin{array}{c}\$ 0.06 \\
0.19 \\
0.31 \\
0 \\
0.01 \\
0.04 \\
0.05 \\
0.12\end{array}$ \\
\hline $\begin{array}{l}\text { Cost without raw materials } \\
\text { Cost of wood }\end{array}$ & $\because$ & $\begin{array}{r}25.8 \\
4.4\end{array}$ & $\because$ & $\begin{array}{l}0.78 \\
0.13\end{array}$ \\
\hline Total Operating Cost & . & $\$ 30.2$ & & $\$ 0.91$ \\
\hline
\end{tabular}

${ }^{a_{F}}$ eedstock $=1,000$ oven dry tons of wood per day.

$b_{G} \& A: 1.62 \%$ of capital cost; property tax \& insurance: $2.0 \%$ of capital cost. Cost of wood: $\$ 6.70 /$ ton (wet) in 1972 dollars. 
THIS PAGE

\section{WAS INTENTIONALLY \\ LEFT BLANK}




\section{REFERENCES}

1. MITRE Corp., Biomass-Based Alcohol Fuels: The Near Term Potential For Use with Gasoline, U.S. Department of Energy, HCP/T4101-03 (August 1978).

2. Peters, Joseph F., and M. Carl Ziemke, Socio-Economic Aspects of a Major U.S. Biomass Alcohol Fuel Program, presented at International Solar Energy Society, Atlanta, Ga. (May 1979).

3. Miller, Dwight L., The Corn Belt-An Energy Belt?, Corn Annual (1979).

4. Lipinsky, E.S., et al., Fuels from Sugar Crops, Battelle-Columbus Laboratories, Columbus, Ohio, BMI-1975 (1976).

5. David, Milton L., et al., Gasohol Economic Feasibility Study, Development Planning and Research Associates, Inc. (July 1978).

6. Ballou, Stephen W., et al., Environmental Residuals and Capital Cost of Energy Recovery from Municipal Sludge and Feedlot Manure, ANL/EES-TM-53 (Aug. 1978).

7. U.S. Environmental Protection Agency, Compilation of Air Pollution Emission Factors, AP 42, Vols. A\&B, 3rd Ed. (May 1978).

8. Water Pollution Control Federation Manual of Practice No. 8, Wastewater Treatment Plant Design.

9. E1ler, B.M,., Road Dust Induced Increase of Leaf Temperature, Environmental Pollution 13 (2):99-107, 1977.

10. Tsao, George T., Cellulosic Material as a Renewable Source, Process Biochemistry (Oct. 1978).

11. Wilke, C.R., Process Development Studies on the Bioconversion of Cellulose and Production of Ethanol, University of California, Berkeley, ERA Citation 03:04259 (Feb. 1978).

12. SRI International, Mission Analysis for the Federal Fuels from Biomass Program, Vol. V, Biochemical Conversion of Biomass to Fuels and Chemicals (Dec. 1978).

13. SRI International, Mission Analysis for the Federal Fuels from Biomass Program, Vol. VI, Mission Addendum (Jan. 1979).

14. Blake, D., and D. Salo, Systems Descriptions and Engineering Costs for Solar-Related Technologies, Vol. IX, MITRE Corp. (June 1977).

15. MRI Report, Continuation of Systems Study of Fuels from Grasses and Grains: Phase 2 and 3, DOE No. EG-77-C-01-4042 (July 1979).

16. Benemann, John R., Biofuels: A Survey, ER-746-SR (June 1978). 
17. Harper, J.P., A.A. Antonopoulos, and A.A. Sobek, Environmental and Economic Evaluation of Energy Recovery from Agricultural and Forestry Residues, Argonne National Laboratory, Report ANL/EES-TM-58 (August 1979).

18. Goss, J.R., Food Forest Wastes -- Low Btu Fuel, Agricultural Engineering (Jan. 1978).

19. SRI International, Mission Analysis for the Federal Fuels from Biomass Program, Vol. IV, Thermochemical Conversion of Biomass to Fuels and Chemicals (Jan. 1979). 


\section{BIBLIOGRAPHY}

B1iss, C., and D.0. Blake, Silvicultural Biomass Farms: Conversion Processes and Costs, MTR-7347, Vol. V, Mitre/METREK (1977).

Ghose, Tarun K., and Ghosh Purnendu, Bioconversion of Cellulosic Substances, J. Appl. Chem. Biotechnol, 28:309-320 (1978).

Grethlein, Hans. R., Chemical Breakdown of Cellulosic Materials, J. Appl. Chem. Biotechnol, 28:296-308 (1978).

Johnson, A.J., and G.H. Auth, Fuels and Combustion Handbook, McGraw-Hill, New York (1951).

Jones, J.L., et al., A Comparative Economic Analysis of Alcohol Fuels Production Options, presented at Alcohol Fuels Technology, 3rd International Symposium, Alsilomar, Calif. (May 1979).

Lipinsky, E.S., et al., Comprehensive Evaluation of Corn, Vol. 5, Systems Study of Fuels from Sugarcane, Sweet Sorghum, Sugar Beets, and Corn, BattelleColumbus Laboratories, Columbus, Ohio (1977).

MITRE Corp., Near Term Potential of Wood as a Fuel, USDOE, HCP/C-4101 (Jan. 1979).

MITRE Corp., Comparative Economic Assessment of Ethanol from Biomass, USDOE, HCP/ET-2854 (Sept. 1978).

Oursborne, C.D., et al., Energy Potential of Texas Crops and Agricultural

Residues, Texas Agricultural Experiment Station, College, Station, Texas

(Feb. 1978).

Perry's Chemical Engineering Handbook, 4th Ed.

SRI International, Mission Analysis for the Federal Fuels from Biomass Program, Vol. I, Summary and Conclusions (Dec. 1978).

SRI International, Mission Analysis for the Federal Fuels from Biomass Program, Vol. II, Mission Selection, Market Penetration Modeling, and Economic Evaluation (Dec. 1978).

SRI International, Mission Analysis for the Federal Fuels from Biomass Program, Vo1. III, Feedstock Availability (Jan. 1979).

U.S. Department of Energy, Biomass Energy Success Stories, HCP/TO 285-01 (March 1978). 
U.S. Department of Agriculture, Statistical Reporting Service, Agricultural Statistice 1977, Washington, D.C. (1977)

Wilke, C.R., et al., Row Material Evaluation and Process Development Studies for Conversion of Biomass to Ethanol, Proceedings of 2nd Annual Fuels from Biomass Symposium; Troy, NY (1978).

Water Pollution Control Federation Manual of Practice No. 11, Operation of Wastewater Treatment Plants. 